\title{
2. BACKGROUND, OBJECTIVES, AND PRINCIPAL RESULTS OF DRILLING THE CLASTIC APRON OF GRAN CANARIA (VICAP) ${ }^{1}$
}

\author{
Shipboard Scientific Party ${ }^{2}$
}

\section{INTRODUCTION}

Ocean islands have played a prominent role in the history of the earth sciences, despite their small number, surface area, and volume, compared to other major geological units of the earth's crust. The first fundamental petrological ideas were formulated by Robert Bunsen and Charles Darwin in their studies on Iceland and the Azores. The decrease in age of oceanic islands, as deduced from the degree of erosion from west to east in the Hawaiian island chain (Dana, 1849), and, among other Atlantic island groups from east to west in the Canary islands (von Fritsch, 1867), were the cornerstones for Wilson's 1963 model of hot spots and plate motions. Subsequently Morgan (1972) expanded this idea in his plume model of ascending mantle material, which was believed to feed the oceanic islands, with plumes serving as a reference frame for determining directions and rates of plate motions. Ocean islands remain the premier geological site to test fundamental models for magma genesis and plate dynamics.

Charles Lyell (1865) held that the large type caldera on La Palma in the western Canary Islands, postulated by Leopold von Buch (1825) to have formed by "updoming," was instead carved by erosion generating huge amounts of sediments. Alexander von Humboldt considered the celebrated Orotava Valley on northern Tenerife below the Cañadas "caldera" at 2000 meters above sea level (masl) to have resulted from a giant landslide.

The role of ocean islands as a significant sediment source was not appreciated, however, until Menard (1956) introduced the concept of archipelagic aprons surrounding ocean islands, deduced entirely from bathymetry. Menard argued that the volume of clastic material shed from the islands into the basins would in many cases even surpass the volume of the islands themselves. Such aprons contain significant amounts of material representing the evolution of the volcanic complex, including material no longer present on the island (Figs. 1 and 2). Most importantly, this includes material from the unexposed and inaccessible submarine stages.

Two recent discoveries highlight the significance of ocean islands as prototype earth systems in which the growth of the islands as a result of mantle processes and their degradation by mass wasting are intimately interwoven. Watts and ten Brink (1985) recognized that layers of volcaniclastic sediments, that could be traced by multichannel seismic methods up to $>200 \mathrm{~km}$ from the Hawaiian island of Oahu, dip toward the island in its immediate surroundings rather than away from the island. They used this inclination to estimate the degree of loading of the lithosphere by the islands and thus the elastic thickness of the lithosphere. The enormous scale of mass wasting is evident from GLORIA side-scan records that reveal that the Hawaiian islands have spawned giant slumps up to $10,000 \mathrm{~km}^{3}$ in volume with blocks to $20 \mathrm{~km}$ wide. These, in turn, have generated major debris flows and distal turbidites that can be traced for several $100 \mathrm{~km}$ from the source volcanoes (Moore et al., 1989; Lipman et al., 1988). Recent work has shown that the Canary Islands erode in similar ways to the Hawaiian Islands, namely through voluminous slumps giving

\footnotetext{
${ }^{\text {t}}$ Schmincke, H.-U., Weaver, P.P.E., Firth, J.V., et al., 1995. Proc. ODP. Init Repts., 157: College Station, TX (Ocean Drilling Program).

${ }^{2}$ Shipboard Scientific Party is given in the list preceding the Table of Contents.
}

rise to debris flows and turbidity currents (Masson and Watts, in press).

The VICAP drilling project was designed to monitor the submarine and subaerial temporal, compositional, volcanic, and chemical growth and mass wasting evolution of a well studied ocean island system by drilling through its peripheral clastic apron and through the edge of the submarine shield phase deposits. We chose Gran Canaria because it has a very long history with magmas of greatly contrasting compositions and because the temporal, volcanic, and compositional evolution of the island has been studied in detail.

Our aim was to understand the way ocean islands evolve and decay from the beginning of the submarine shield stage through the highly evolved and erosional phases. The evolution of the volcanic apron around Gran Canaria and the detailed correlation with the land record is designed as a case history study, a model that will allow us to assess the past volcanic, petrologic, and plate tectonic environments of sedimentary basins adjacent to productive volcanic source areas as well as marine volcaniclastic successions drilled in the ODP program.

\section{BACKGROUND}

\section{Volcanic aprons}

A volcanic apron peripheral to an oceanic island consists of three main facies above the central or core facies and is made up of extrusive and intrusive igneous rocks (Schmincke, 1994; Fig. 1):

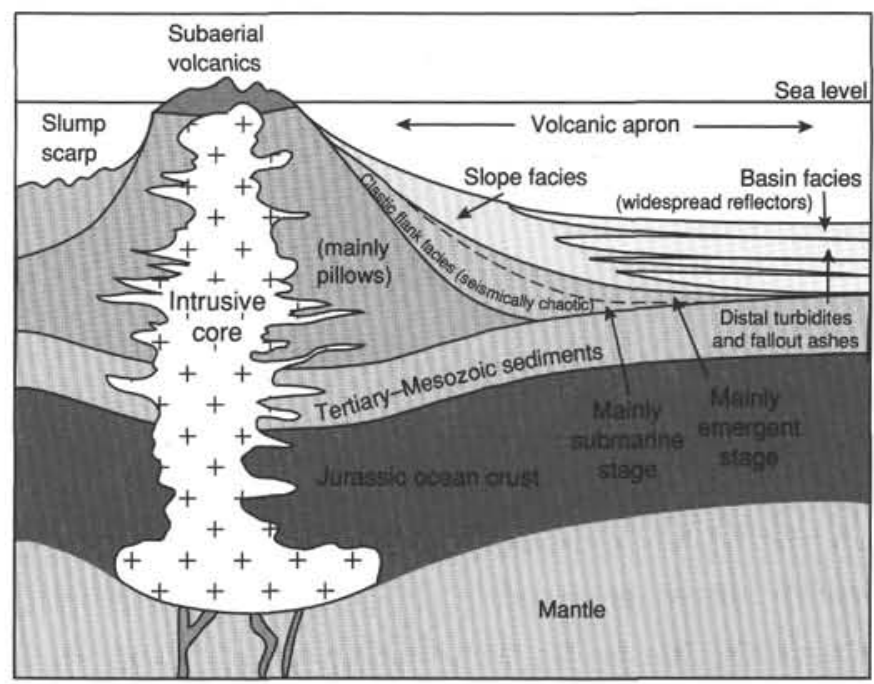

Figure 1. Schematic drawing of ocean island and its clastic apron. The volcanic apron consists of the "seismically chaotic" flanks of the island, made up dominantly of hard volcanic rocks including pillow lavas, pillow breccias, debris-flow deposits, and slump blocks, overlying the core facies of extrusive and intrusive igneous rocks, the basin facies, characterized by widespread reflectors representing volcaniclastic mass-flow deposits (debris flows, turbidites), and ash fallout layers. From Schmincke (1994). 
Figure 2. Three schematic growth stages of a volcanic ocean island as reflected in three main types of submarine volcaniclastic rocks drilled at DSDP Site 397 (Leg 47A) $\sim 100 \mathrm{~km}$ south-southeast of Gran Canaria. From Schmincke (1982).

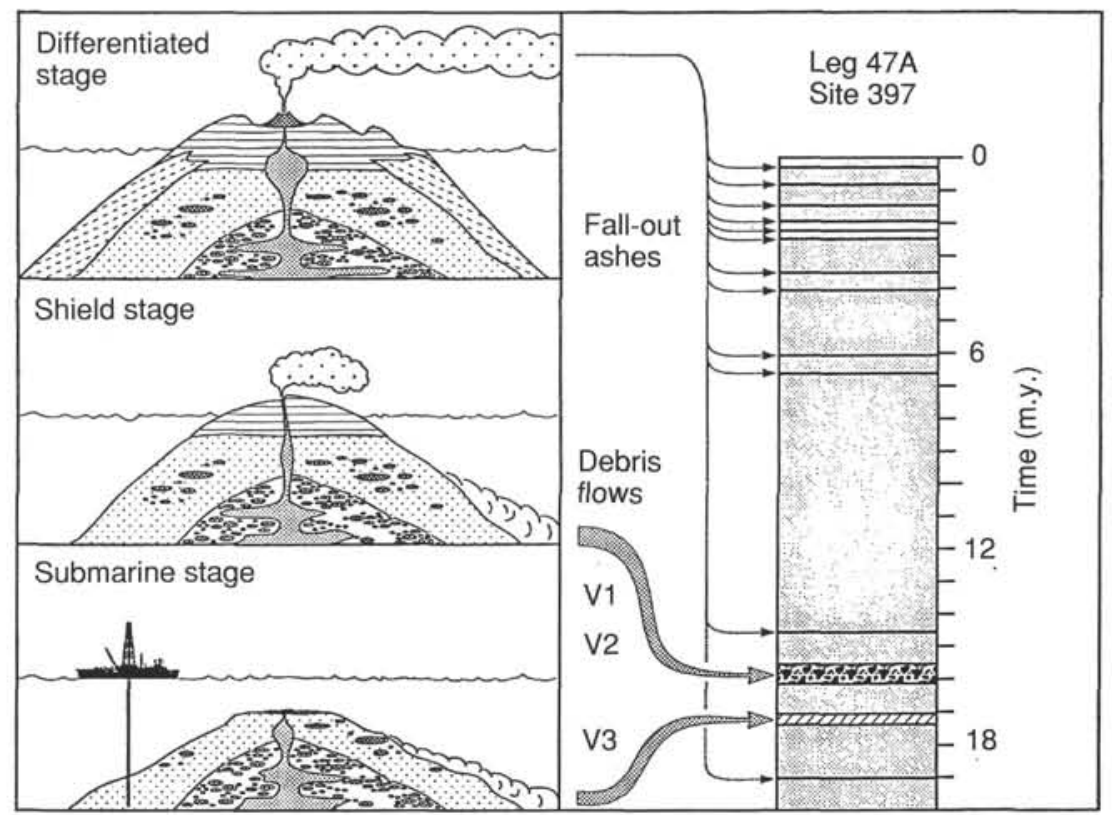

1. Flank facies comprising the seismically chaotic apron.

The higher velocity and "seismically chaotic" flank with velocities around $3.4-4 \mathrm{~km} / \mathrm{s}$ is characterized by discontinuous reflectors, rough topography, and has been called chaotic seismic facies or volcanic apron by some authors (e.g., Wissmann, 1979; Holik et al., 1991).

The interior of the seamount stage of a volcanic island is thought to consist largely of intrusives, pillow lavas (densely packed and nonvesicular at depth, becoming increasingly vesicular and interlayered with pillow breccias and pillow fragment breccias), debris flows, and primary and resedimented hyaloclastites upwards. Rocks from the core facies and the clastic cover (flank facies) are well exposed in an uplifted section of the submarine portion of La Palma (Staudigel and Schmincke, 1984).

The dominantly clastic envelope around the core can be subdivided into pillow breccias and various types of hyaloclastites and flow deposits that were generated during the shallow submarine, emergent, and subaerial stages and were redeposited down the flank of the seamount. The clastic hyaloclastite cover may extend appreciably beyond the core facies. The outer limits of the seismically defined "basement" flanks are identifiable in the profiles down the slopes of Gran Canaria, Tenerife, and Fuerteventura, although the lithologic and seismic boundaries between the flank and the basin facies are not always clear (Funck et al., in press).

The seismically defined flanks are overlain by the sedimentary part of the volcanic apron which consists of two main facies:

2. Slope facies.

The slope facies, above the seismically chaotic flank facies, are characterized by slumps, discontinuous bedded and massive units, debris flows, erosional channels, etc. It corresponds approximately to the submarine morphological slope of an island. This facies extends roughly from the present shore line of Gran Canaria to $\sim 45 \mathrm{~km}$.

3. Basin facies.

The slope facies grades laterally into the basin facies which is characterized by well developed, more continuous and flat reflectors. It consists of diverse types of volcaniclastic deposits including ash fall layers, debris flows, turbidites, and other volcaniclastic material generated during eruptions and by erosion of preexisting volcanic rocks. It may also contain slump sheets recording larger volcanic or slope failure (slumps) relocating sediments initially deposited higher on the slope and destabilized by earthquakes, sea level changes, or other causes. The distal facies extends for hundreds of $\mathrm{km}$. Very distal fine-grained volcanic turbidites from the Canaries can be traced to the area of the Madeira Abyssal Plain $1000 \mathrm{~km}$ to the west (e.g., Masson, 1994).

\section{Geophysical and Geological Setting}

The Canarian archipelago built on the African continental slope and rise consists of seven major islands: Lanzarote and Fuerteventura to the east, Gran Canaria, Tenerife and Gomera in the center and La Palma and Hierro in the west (Fig. 3). Three islands (Gran Canaria, Tenerife, La Palma) are $>2000 \mathrm{~m}$ high and Tenerife, dominated by Pico de Teide, is the third largest oceanic volcano on earth. The archipelago extends between 115 and $600 \mathrm{~km}$ west of the African coast and for 100-200 km north-south. Total surface area of the islands is $\sim 7500 \mathrm{~km}^{2}$. The very small volcanic island remnants of the Selvagens Islands, Concepcion Bank to the north and seamounts to the southwest are regarded as part of the Canary Island volcanic province. There are few groups of volcanic islands with such long histories of eruptions (Fig. 3), spanning >15 m.y. on some individual islandsand such an enormous variety of volcanic and plutonic rocks, ranging from highly silica - undersaturated melilite nephelinites to peralkaline rhyolitic welded tuffs.

The Canary Islands are oceanic intraplate islands in many ways resembling the evolutionary stages of the Hawaiian Islands (Schmincke, 1976). Differences between the Hawaiian and Canarian evolution include the following:

1. The volume of lavas from the shield stages in Gran Canaria is smaller than on Hawaii.

2. The types of shield volcanoes differ among the Canaries and therefore between the Canaries and the Hawaiian Islands.

3. The number of post-erosional or rejuvenated stages in the Canary Islands is higher than in the Hawaiian Islands.

4. Volcanic activity following the initial shield stage lasts much longer on the Canary Islands than in Hawaii.

5. The volumes of evolved rhyolitic, trachytic, and phonolitic magmas (e.g., on Gran Canaria and Tenerife) are very high, in the former amounting to probably $>500 \mathrm{~km}^{3}$. 


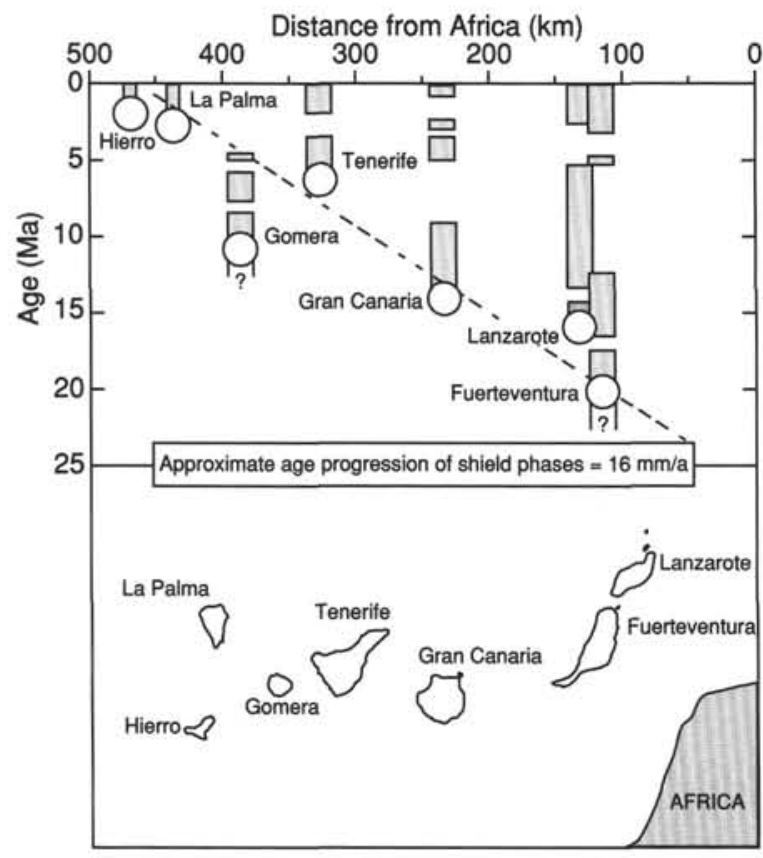

Figure 3. Age progression of shield phases in the Canary Islands. Age data of the shields are not well constrained for most islands. Note the large number of magmatic phases on most islands. Nearly all islands have been active in historic and prehistoric times. From Schmincke (1994).

6. No large slump blocks have yet been discovered within the sedimentary apron around Gran Canaria although one major scar in the southwest (Hogarzales Basin) formed in the shield volcano prior to the end of basaltic shield volcanism.

7. The thickness of the lithosphere in the vicinity of the Canary Islands may be around $100 \mathrm{~km}$.

8. Abundant seamounts north and south of the Canaries and the very elongate ridge encompassing the eastern Canaries and Concepcion Bank form a volcanic belt parallel to the African coast, contrasting with the temporal east-west progression of the island chain.

9. A definite regional compositional trend in the Canaries, the alkalinity being highest in the western and lowest in the eastern islands, possibly reflecting the sampling by the ascending magmas of different zones of the broad melting anomaly, contrasts with the relatively well focused Hawaiian plume.

In summary, the thickness and rigidity of relatively old lithosphere leading to increased depth of magma generation, very slow plate motion, broad and more diffuse partial melting anomaly in the mantle and the proximity to the boundary between continental and oceanic lithosphere all contribute to the much more heterogeneous magmatic, temporal, structural and volcanic evolution of the Canaries compared to Hawaii. These differences are modifications, however, of a fundamental pattern which consists of a main basaltic shield making up $90 \%$ by volume or more of an island followed after erosional intervals at later stages of less voluminous and more alkalic, mafic magmas and some differentiates and a general age progression in rough harmony with known rates and directions of plate motion in this area.

\section{Sedimentary Basins}

The main east-west oriented chain of islands, from Fuerteventura in the east to La Palma and Hierro in the west, is flanked by two ba- sins, one north of the chain and one south. Both are oriented northeast-southwest at their eastern ends but change to east-west trends in the western part. Both basins developed as the island chain grew, principally from east to west.

The depth of the northern basin ranges from about $3000 \mathrm{~m}$ in the northeast to $4000 \mathrm{~m}$ in the west between La Palma and the Selvagens. It is bounded to the east by the north-northeast striking Canary Ridge which consists of the Miocene islands of Fuerteventura and Lanzarote, separated from each other by a very shallow strait ( $40 \mathrm{~m}$ water depth) while Lanzarote is separated from Concepcion seamount in its northeastern continuation by water depths of $\sim 1800 \mathrm{~m}$. To the north, the basin is bounded between Selvagens Islands and Concepcion Seamount by submarine ridges and seamounts south of Dacia Seamount. Maximum water depths in the channel between Fuerteventura and Gran Canaria are 1500 and $2200 \mathrm{~m}$ between Gran Canaria and Tenerife, and $2700 \mathrm{~m}$ between Tenerife and La Palma. The islands rise to $2423 \mathrm{~m}$ (La Palma), $3711 \mathrm{~m}$ (Tenerife), $1980 \mathrm{~m}$ (Gran Canaria), and $\sim 700 \mathrm{~m}$ (Fuerteventura). The strait between Selvagens and an unnamed seamount $125 \mathrm{~km}$ to the west is ca. $3400 \mathrm{~m}$ deep. The basin is open to the west. West of the La Palma-Selvagens line, the seafloor steepens rapidly to $4600 \mathrm{~m}$ and then more gently to the Madeira Abyssal Plain $(5300 \mathrm{~m}) 1000 \mathrm{~km}$ to the west.

The southern basin, the South Canary Channel, is flanked to the east and southeast by the African continental margin and to the north by the island chain. It steepens from $\sim 2000 \mathrm{~m}$ south of Fuerteventura to $3800 \mathrm{~m}$ south of Hierro.

\section{The Mesozoic Ocean Crust}

There is a present consensus that the boundary between oceanic and continental crust is situated east of the East Canary Rise, perhaps seaward of the zone of salt diapirs that parallels the African coast (e.g., Wissmann, 1979; Watkins and Hoppe, 1979). The most recent and detailed seismic data indicate that the base of the oceanic crust is at $~ 15-16 \mathrm{~km}$ beneath Gran Canaria and at 13-14 km below the North Canary Basin north-northeast, off Gran Canaria, and that the oceanic crust in this area is $\sim 6 \mathrm{~km}$ thick (Ye et al., unpubl. data). Abundant xenoliths of MORB tholeiitic composition, ranging from basalt to gabbro and dated as approximately $160 \mathrm{Ma}$, which occur in fanglomerates sandwiched between the basaltic shield lavas and overlying ignimbrite series on Gran Canaria and also in lavas and spatter of the 1949 eruption of San Juan Volcano on La Palma indicate major uplift of crustal blocks of several thousands of meters possibly prior to formation of the basaltic shield (Schmincke, 1994).

\section{Mesozoic and Paleogene Sediments}

Gran Canaria is underlain by about $2-3 \mathrm{~km}$ of Mesozoic to Neogene sediments (Ye et al., unpubl. data). About $1300 \mathrm{~m}$ of sediments drilled at Site 397 during DSDP Leg 47 (Pt. 1) 110 km southeast of Gran Canaria begin with about $\sim 130 \mathrm{~m}$ of fine-grained compacted Cretaceous (Hauterivian) silt- and claystones separated from lower Miocene radiolarian-nannofossil mudstone by a 100 Ma hiatus that still remains unexplained. About $1300 \mathrm{~m}$ of sediments were missing and Arthur et al. (1979) interpreted the gap as probably caused by geostrophic currents intensified by the late Oligocene initiation of the strong circum-Antarctic bottom-water circulation after the separation of Australia from Antarctica. An alternative is that growth of the Canary Islands generated currents that led to massive erosion along the slope. Debris flows (pebbly mudstones) dominate the middle Miocene. These allochthonous sediments, believed to have been derived from the African continental margin by slumping, occur in smaller units as late as the Late Miocene. Nannofossil chalks and marls dominate the late Neogene and diatoms become abundant in the Quaternary. 


\section{Seismic Structure}

Luyendyk and Bunce (1973) postulate that volcanic activity in the area of the Canaries began at least as early as the Late Cretaceous based on tentative identification of acoustically stratified sections in reflection profiles in the area as volcanic detritus derived from the Canaries. A seismic section north of the Canaries and east of Dacia Bank at $\sim 31^{\circ} \mathrm{N}$ has been interpreted as indicating submarine volcaniclastic aprons of Eocene or slightly pre-Eocene age (Watkins and Hoppe, 1979). These authors suggest that what they call the Canary Arch on seismic evidence $\sim 100 \mathrm{~km}$ northeast and in continuation of Concepcion Bank was first uplifted between middle Cretaceous and the Miocene. Holik et al. (1991) interpreted a zone of high layer 3 velocities and units of chaotic seismic facies between $31^{\circ} \mathrm{N}$ and $33^{\circ} \mathrm{N}$ as representing early Tertiary volcanic and intrusive activity. They interpreted the seismic data as evidence for the location of the Canary Island hot spot (Morgan, 1983) from 50 to $60 \mathrm{Ma}$ and suggest a northeast-southwest age progression of the plate over the hot spot whose present position they now place beneath Hierro.

In the Canary Basin north of Gran Canaria, the volcaniclastic island flank is well defined by reflection and refraction data. It has seismic $P$-wave velocities between 3.4 and $4.6 \mathrm{~km} / \mathrm{s}$ extending out to a distance of 44 to $72 \mathrm{~km}$ off the coast and is underlain by a $\sim 2.5-3 \mathrm{~km}$ thick prevolcanic sediment layer characterized by lower velocities of $3.0-3.2 \mathrm{~km} / \mathrm{s}$ (Ye et al., unpubl. data). Some of the widespread conspicuous seismic reflectors in marine sediments around the Canary Islands have been identified as volcaniclastic debris flow sheets (Wissmann, 1979; Schmincke and von Rad, 1979). Maps of the main deep reflector (R7) in the apron south of Gran Canaria (Wissmann, 1979) clearly show that the approximate flank of the shield, probably the time interval of $\sim 14-16 \mathrm{Ma}$, decreases from $\sim 300 \mathrm{~m}$ depth at 20 to $40 \mathrm{~km}$ from the island to $>600 \mathrm{~m}$ at 50 to $80 \mathrm{~km}$ in the center of the basins (Funck et al., in press). The southeastern and northern apron basins differ significantly in that reflectors thought to be correlative with the southern ones are deeper in the north than in the south at the same distance from the island, reflecting much higher sediment flux during the Pliocene and Quaternary toward the north and northeast than from the southern part, where volcanic activity had practically ceased $\sim 10 \mathrm{Ma}$.

Seismic refraction data indicate a $1.5-$ to $2.0-\mathrm{km}$-thick low velocity $(2-3 \mathrm{~km} / \mathrm{s})$ upper section beneath some islands such as Tenerife (Dash and Bosshard, 1968; Bosshard and Macfarlane, 1970). This is similar to the submarine series on La Palma (Staudigel and Schmincke, 1984) where the dominance of hyaloclastites and pillow breccias in the upper part of the section would be expected to show low velocities of this magnitude.

\section{Submarine Growth Stages}

The submarine and subaerial development of the Canaries is reflected in volcaniclastic sediments encountered in DSDP Site 397 , drilled during Leg 47.(Pt.1), 100 km south-southeast of Gran Canaria (Schmincke and von Rad, 1979; Schmincke, 1982) (Fig. 2). Hyaloclastite debris flows are interpreted as representing the submarine stage of an island. They are overlain by volcaniclastic debris flows thought to reflect the rapid growth of an island during the shield stage, a very large amount of clastic debris being generated during the transition period seamount/island by phreatomagmatic and magmatic explosive activity as well as erosion of freshly formed clastic deposits. Younger ash layers of DSDP Sites 369 and 397 reflect later, differentiated, subaerial stages of an island (Fig. 2), such as the 13.5- to 14-Ma rhyolite and 13.5- to 9.5-Ma trachyphonolitic ashes and the Pliocene phonolitic ash layers from Gran Canaria.

\section{Subaerial Growth Stages}

Most of the subaerial part of the islands is made of basaltic shields, consisting of thin, moderately alkalic basaltic lava flows, generally less than a few hundred meters in lateral extent, and local scoria cones. The subaerial portions of these shield series are now up to $\sim 1000 \mathrm{~m}$ thick in Gran Canaria and Tenerife but may have exceeded $1500 \mathrm{~m}$ or even $2000 \mathrm{~m}$ in height judging from the youthful westernmost islands Hierro and La Palma. All islands contain evolved rock series, mostly phonolites, while Gran Canaria felsic rocks encompass a wide spectrum of trachytes, rhyolites, and phonolites. Younger volcanic episodes occurred on all islands typically consisting of scoria cones and associated lava flows, although in Tenerife and Gran Canaria central volcanoes with highly differentiated magmas developed during later stages.

\section{Age of the Canary Islands}

Our understanding of the temporal evolution and regional age progression of Canary Island volcanism is based entirely on the subaerially exposed rocks. Fossils in sediments interfingered with volcaniclastics in the subaerially exposed Fuerteventura basal complex suggest that volcanism on the easternmost islands may have begun at 70-80 Ma (Le Bas et al., 1986).

The subaerial part of Gran Canaria is not older than mid-Miocene ( 14.3-15.5 Ma), as shown by abundant $\mathrm{K} / \mathrm{Ar}$-age data (McDougall and Schmincke, 1976; O'Connor and Schmincke, unpubl. data).

The Tenerife shield basalts were dated as ca. $~ 5-8.5$ Ma but most ages are between 5 and $7 \mathrm{Ma}$ (Ancochea et al., 1990). Evidence from detailed seismic reflection studies and seismic mapping of the flank facies of the volcanic aprons around Gran Canaria supports the interpretation that the shield phase of Tenerife is significantly younger than that of Gran Canaria which it overlaps in the channel between both islands (Funck et al., in press). The shields of Hierro are $<1 \mathrm{Ma}$ and La Palma <3 Ma (Staudigel and Schmincke, 1984; Ancochea et al., 1993).

The shield-building phase is followed in practically all islands by a major erosional hiatus lasting $\sim 3$ to $5 \mathrm{~m}$.y., judging from limited data (Fig. 3). The duration of this gap, which is of some importance in establishing boundary conditions for magma generating processes, may decrease from the eastern to the western islands (Schmincke, 1976).

Historic volcanic eruptions occurred on Lanzarote, Tenerife, and La Palma. Prehistoric eruptions have been dated from Gran Canaria $(3075 \pm 50 \mathrm{Ma})$ and the youngest eruptions on Fuerteventura are probably not much older, judging from their well-preserved surface features. Thus, the entire Canarian Archipelago can be considered as an active volcanic area. In fact, the Canaries are the most active volcanic island group among Atlantic volcanic islands, next to Iceland and the Azores.

\section{Geology of Gran Canaria}

Gran Canaria $\left(28^{\circ} 00^{\circ} \mathrm{N}, 15^{\circ} 35^{\top} \mathrm{W}\right)$ is the central island of the Canarian archipelago some $200 \mathrm{~km}$ from the northwestern African passive continental margin. Gran Canaria is very well exposed and well studied. Composition and age of the submarine part of the island are unknown. The subaerial Miocene Phase started with the rapid formation ( 1 m.y.) of the exposed tholeiitic to mildly alkalic shield basalts (Fig. 4). At $\sim 14 \mathrm{Ma}$, the basaltic shield phase was followed by a 0.5 m.y. volcanic phase of trachytic to rhyolitic composition ( 15 chemically and mineralogically distinct pyroclastic flow cooling units of the Mogan group) making up what is the largest volume of silicic volcanic rocks on any oceanic intraplate volcanic island. The ash flows erupted at intervals of 0.03-0.04 m.y. (Bogaard et al., 1988). More than $500 \mathrm{~km}^{3}$ of silica-undersaturated nepheline trachyphonolitic ash flows, lava flows, and fallout tephra of the Fataga group, and rare basanite and nephelinite dikes and lavas, erupted between $\sim 13$ and $\sim 9.5 \mathrm{Ma}$, accompanied by intrusive syenites and a large trachyticmonolitic cone sheet swarm in the central caldera complex lasting until $\sim 8 \mathrm{Ma}$. Following a major nonvolcanic hiatus lasting approximately 3-4 m.y., the Pliocene Phase began with the local emplacement of 


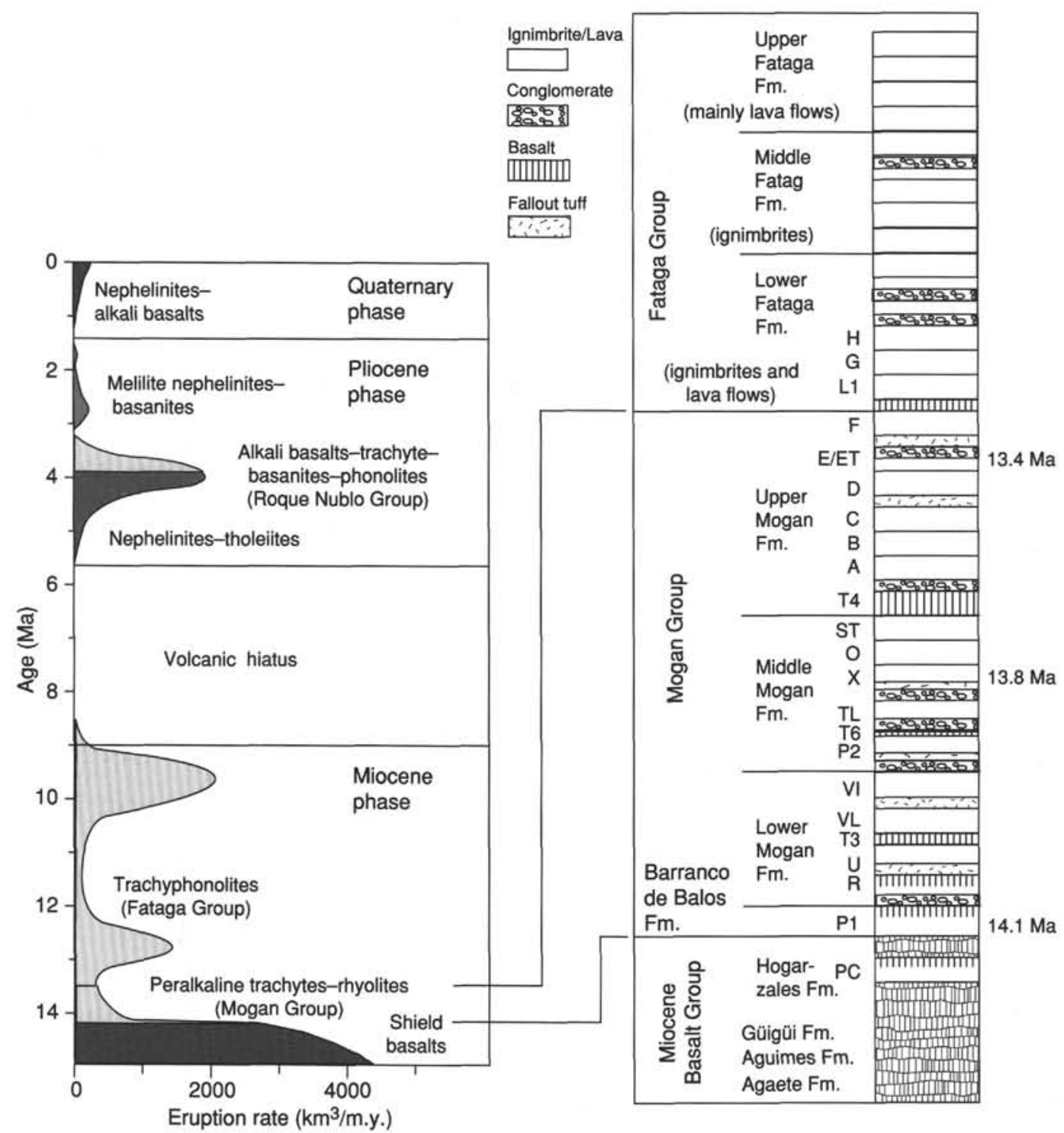

Figure 4. Volume-eruption rate relationship of major magmatic phases during the Miocene, Pliocene, and Quaternary volcanic phases on Gran Canaria. From Schmincke (1994) after Schmincke (1976) and Hoernle and Schmincke (1993a).

small volumes of nephelinites, basanites, and local tholeiites at $\sim 5$ $\mathrm{Ma}$. The eruption rate increased between 5 and $4 \mathrm{Ma}$ and the lavas became more $\mathrm{SiO}_{2}$-saturated, ranging from basanites to alkali basalts to tholeiites. Between $\sim 4$ and $3.4 \mathrm{Ma}$, a large complex stratocone was built, rising high above the deeply eroded Miocene shield (Roque Nublo Volcano). Lavas, encompassing alkali basalts, trachytes, basanites, and phonolites, are intercalated with massive hauyne phonolite breccia flows, ash falls, and pumice flows, which were intruded by trachytic and hauyne phonolite domes. Following a possible brief hiatus in volcanism, there was a resurgence in volcanism, during which only highly undersaturated mafic volcanics were erupted. These (melilite) nephelinites to basanites (3.2-1.7 Ma), may represent the largest volume of highly undersaturated mafic lava flows known from oceanic islands.

Voluminous mafic Quaternary volcanism occurred almost exclusively in the northeastern half of the island. The oldest dated Pleistocene Phase volcanics are $1 \mathrm{Ma}$ nephelinites, whereas the more recent Quaternary and Holocene volcanics are predominantly basanites, with rarer eruptions of alkali basalt and local hauyne tephrite.

\section{SCIENTIFIC OJECTIVES}

\section{Age, Composition, and Volcanic Evolution of the Shield Phase of Gran Canaria}

\section{Age}

A major problem in dating the inception of oceanic intraplate volcanism and monitoring the chemical evolution is the fact that most of the volume lies under water. Recent seismic evidence suggests that the volume of the submarine shield may be much larger than previously thought so the subaerial volume may constitute $<5 \%$ of the entire edifice. We expect to be able to date the shield stage of Gran Canaria more closely through drilling to the base of the volcanic apron. Volcaniclastic material from the shield phase of Fuerteventura is expected to be encountered below those of Gran Canaria. Can the time gap of the submarine deposits of both shields be specified in time and composition more precisely than from the land record? 


\section{Compositional Evolution of Mantle Sources and Magmas}

Major changes in the composition of several distinct mantle sources for primitive magmas have been found throughout the subaerial development of Gran Canaria (Hoernle and Schmincke, 1993a, b). The observed variations in the subaerial portion, making up only $\sim 5 \%$ of the volcano, are not representative of the entire volcano. The isotopic composition of the subaerial volcanics on Gran Canaria change significantly with age, possibly reflecting greater influence of lithospheric/asthenospheric assimilation in the late stages of ocean island volcanism. If this is the case, then the voluminous submarine volcanics, formed when the volcano was directly above the plume, should more closely reflect the true isotopic composition of the plume.

\section{Volcanic Evolution of Gran Canaria Reconstructed from Apron Sediments}

\section{Transition Deep Submarine-Shallow Submarine-Subaerial}

Moore and Fiske (1969) have demonstrated that the upper $~ 1000$ $\mathrm{m}$ of the submarine part of the large complex shield volcano of Hawaii is made up of fragmental rocks (hyaloclastites) formed when the precursor seamount rose to approximately several hundred meters below sea level, at which low pressure it started to erupt explosively owing to degassing of the lava. Staudigel and Schmincke (1984) and Schmincke and von Rad (1979) have expanded this model by combination with the study of the uplifted pillow series on La Palma and debris flows believed to have been generated during the emergent shield stage.

This first attempt to drill through the edge and into the flanks of the submarine flank of an oceanic volcano should greatly increase our understanding of the growth processes of submarine volcanoes. Can a true submarine phase (i.e., eruption below the volatile fragmentation depth) be distinguished from the emerging phase of a shield volcano? Particle textures, structures, and accumulation rates will ground this discussion.

\section{Volcanic Evolution on Land}

The subaerial island source area has a long-term subaerial record of temporally and chemically distinct magmatic phases with datable mineral phases. Thus, the submarine and subaerial growth and destruction should be reflected in some detail in the volcaniclastic apron that interfingers with nonvolcanic biogenic and continent-derived clastic material. The seamount and island evolution, as deduced from deep drilling into the apron, can then be compared to the volcanic, temporal, and compositional evolution reconstructed from the study of products exposed on land. Compositionally, structurally, and texturally distinct units of volcaniclastic sediments should be correlatable between the land record and the deposits drilled, based on chemical and mineralogical differences and particle characteristics of volcanic clasts and their stratigraphic position.

In detail, the major differences in the geologic evolution of southern and northern Gran Canaria as well as contributions from neighboring islands should be reflected in the different sites. Similarly, it is expected that the nonvolcanic sedimentary input into the northern basin, shielded from submarine contributions from Africa-but not from aeolian input - by the Eastern Canary Ridge, at least as early as Miocene, differs appreciably from the South Canary channel south of the island chain where sediment flux from Africa down the continental slope and rise has been unimpeded by island barriers until today.

\section{Dating}

A major element of this VICAP research program will be high precision single-crystal ${ }^{40} \mathrm{Ar} /{ }^{39} \mathrm{Ar}$ age dating with the aim of monitoring the island and basin evolution in detailed time slices as small as $100,000 \mathrm{yr}$. This method will be extensively applied because of the abundance of K-feldspar and biotite-bearing highly evolved rhyolitic, trachytic, and phonolitic magmas especially on Gran Canaria between 14 and $3.5 \mathrm{Ma}$. Time-scale correlation of physically dated ash layers, paleomagnetics, biostratigraphy, and distinct seismic reflectors will be a major objective in order to constrain the paleomagnetic time scale in the middle Miocene between $\sim 10$ and $14 \mathrm{Ma}$.

\section{Land-Sea Transitions and Lithology vs. Climate Control on Flux of Volcanic Detritus into the Sea}

Criteria lack by which one can distinguish primary volcanic particles produced by explosive eruptions or flow of lava into the sea and modified little during subsequent transport to the depositional site and volcanic particles produced by erosion of pre-existing rocks. The clear alternation of highly productive volcanic phases and longer erosional periods on Gran Canaria, and the fact that many of the Miocene ash flows entered the sea, provides an excellent opportunity to better understand how primary volcanic flows are modified in their mode of transport and effect on particles when they continue under water. We also expect to distinguish primary from secondary volcaniclastic fragments and deposits and thus be able to date and quantify erosional and volcanic episodes and compare the computed rates and volumes with those derived from the more accessible, but less complete, land record.

A comparison of transfer rates of volcanic detritus during this time versus the entirely erosional period between $\sim 9$ and $5 \mathrm{Ma}$ will be very instructive in comparing nonvolcanic versus volcanically constructive periods.

Physical properties such as grain density, magnetic susceptibility, and natural gamma measured routinely aboard ship should help to estimate the percentage of volcanic material in the fine-grained sediments not amenable to microscopic study.

\section{Event Stratigraphy}

Ash flows and ash falls and their marine counterparts are distinct major volcanic events. Much of the volcanic sediment is transferred from the subaerial flanks of volcanic islands into adjacent basins, and thence to the abyssal plain, by slumps, slides, debris flows, and turbidites. Major objectives include identifying and dating the major events and reconstructing the dynamic event stratigraphy within the volcanic apron and correlating major events with distinct seismic reflectors.

\section{Provenance, Frequency, Volume Calculations of Transported Sediments; 3-D Modeling of Basin Evolution}

The drilling and available seismic data will provide an excellent data base for 3-D modeling of the clastic apron of Gran Canaria and the eastern Canary Basin. The limited size of the clastic apron, high resolution stratigraphy from detailed pre-site surveys and the drilling, together with identification of sediment geometry from seismic surveys, and point source of sediment fluxes will facilitate the development of a model. The main topic is the reconstruction of the system (i.e., sediment source, dispersion, and fill).

Determination of sediment budgets for material transferred from the submarine and subaerial stages of the Canary Islands by volcanic processes and erosion will be facilitated by drilling the different facies areas of the apron on the two contrasting sedimentary basins north and south of Gran Canaria.

\section{Diagenesis and Hydrothermal Alteration}

We will assess chemical fluxes between components, especially volcanic glass and pore waters, focusing on volcaniclastic units differing in composition (e.g., basaltic-rhyolitic-phonolitic) interlayered with biogenic sediments. The glassy nature of volcaniclastic debris makes it an especially sensitive indicator of diagenetic processes. Which elements will reflect the strongly contrasting chemical composition of the volcaniclastics in the composition of pore waters? 
The timing of hydrothermal and low-temperature circulation and the mass budget of element exchanges related to the submarine growth stage of Gran Canaria will be investigated by determination of diagenetic gradients, authigenic phases, and alteration of volcanic glass.

\section{Paleobathymetry, Paleoenvironments, and Paleoceanography}

The VICAP drill holes provide important perspectives for the reconstruction of paleobathymetry and paleoceanography of the eastern North Atlantic Ocean around the Canary Islands. It will be of particular importance to investigate the paleobathymetry of the volcaniclastic apron by means of (1) reconstructing the CCD and other dissolution interfaces, (2) analyzing in detail benthic foraminifers, as qualitative depth indicators, and (3) comparing carbon isotope ratios in the shells of calcareous benthic organisms and planktonic surface water dwelling organisms, particularly the carbon isotopes of benthic organisms during periods of elevated carbon contributions in the course of volcanic activity maxima.

\section{Response of the Lithosphere to Loading and Heating during} Magmatic Activity and Enhanced Levels of Stress Associated with Temporal Changes in Plate Dynamics

The bathymetry around oceanic intraplate volcanic complexes is determined by (1) the density-, thickness-, and age-dependent static equilibrium of underlying oceanic basement, (2) subsidence by loading with the volcanic edifices and their volcaniclastic aprons (e.g., Watts and ten Brink, 1989), (3) subsidence by loading with continent-derived sediments, and (4) uplift by reheating of the lithosphere due to thermal anomalies in the mantle associated with intraplate volcanism or by dynamic uplift.

In the case of the Canary Islands, the relative scale of these effects is a matter of debate. The zone of intraplate deformation offers the prospect of making quantitative progress in the study of lithospheric response to enhanced levels of stress associated with temporal changes in plate dynamics. Identification of marker beds enables volumetric interpretations and reconstruction of the three-dimensional structure of the volcaniclastic apron, which in turn allows deduction of the spatial and temporal response of the lithosphere/mantle system (intraplate deformation and mechanics of flexure) to gravitational loading. The sediment aprons around the islands preserve direct and indirect evidence of volcano growth and vertical movements. It is one of the objectives of VICAP to study the interplay of vertical loading and in-plane stresses using high-resolution data on the temporal evolution of the area. For this purpose, the flexural behavior of the lithosphere using depth-dependent rheologies and variations in stress level associated with this particular tectonic setting will be modeled.

\section{Northern Sites (VICAP)}

We proposed to drill two sites north and northeast of Gran Canaria to penetrate the "seismic apron" on the island flank (VICAP-1a) and the medial/facies (VICAP-2a) in the North Canary Basin. The northern sites are expected to reflect volcanism, erosion, and sedimentation that differ significantly from the south. We hope to penetrate the lowermost part of the Gran Canaria as well as Fuerteventura(?) aprons. These data will show if the age of volcanism in the eastern Canary islands is compatible with a hot spot at 20 to $30 \mathrm{Ma}$ and an age progression of volcanism from northeast to southwest. While the deposits from the submarine stage of Gran Canaria may, or may not, differ in composition and type from those in the south, the younger volcaniclastic deposits should reflect a volcanic and erosional evolution that differs appreciably from that in the south. We expect sufficient ash fall layers and distal submarine equivalents of ash flows to date the deposits by single crystal laser analysis. Phonolitic deposits from the Fataga Group ( 13-10 Ma) should dominate. We also expect much more erosional detritus from the Miocene rhyolitic and trachytic stages. By far the largest difference should show up in the
Pliocene to Recent deposits. Primary and eroded products from the $>100 \mathrm{~km}^{3}$ Roque Nublo stratovolcano ash flows, lavas, debris flows, and lahars were largely channeled to the north and northeast, and the thick Las Palmas clastic fan on land indicates the huge volume of these deposits. Detritus from eroded basanitic to nephelinitic flows should dominate the volcaniclastic deposits from the last 2 m.y., probably interspersed with some fallout tephra layers from Tenerife. The nonvolcanic sediments should show only minor influx from Africa (siliciclastic components, organic matter).

\section{Southern Sites (VICAP)}

We proposed to drill two holes southeast and southwest of Gran Canaria, penetrating the medial facies (VICAP-4 and VICAP-7) in the South Canary Basin. These sites should provide a fairly complete sequence of volcaniclastic deposits derived from the submarine and southern subaerial volcanic stages, especially many submarine equivalents of the large ash flows that entered the sea along the paleocoastline of the island between $\sim 14$ and $10 \mathrm{Ma}$.

This will be complemented by analysis of K-feldspar-bearing ash layers from Tenerife, expected to be abundant in the southwestern and possibly also northern apron in deposits younger than $\sim 2 \mathrm{Ma}$. Tephra layers will cover a wide area and should make excellent marker horizons.

Very abundant ash-fall layers and distal submarine extensions of ash flows that entered the sea at the southwestern coast of Tenerife during the past $2 \mathrm{~m}$.y. should dominate the uppermost part of the section in the southwestern site. The number and ages of ash fall layers erupted from the Pico de Teide Volcano on Tenerife should be abundant, because the site is downwind from the island. Information on paleowind directions will be gained by the reconstruction of depositional fans of Plinian ash falls, especially those from the abundant explosive eruptive phases of Pico de Teide volcano on Tenerife.

\section{Pre-cruise Site Survey around Gran Canaria}

Prior to Leg 157 drilling, geophysical pre-site surveys were conducted around Gran Canaria (VICAP). The main pre-site-survey for the VICAP-part of Leg 157 was conducted during Meteor Cruise M24 in April-May 1993 when $2217 \mathrm{~km}$ of high resolution reflection seismic profiles were acquired (Fig. 5; Schmincke and Rihm, 1994). The seismic equipment was supplied by the Department of Earth Sciences, University of Aarhus. The acoustic pulses were generated by a cluster of four synchronously fired 0.651 sleeveguns (Halliburton). The operating pressure was about 100 bar. The gun-cluster was towed at a depth of approximately $2 \mathrm{~m}$. Depending on the water depth the firing rate was $5,7.5$, or $10 \mathrm{~s}$ corresponding to shot distances 12.5 , 18.75 , and $25 \mathrm{~m}$, respectively, at a cruising speed of $5 \mathrm{kt}$.

Data were recorded by a 24-channel Teledyne streamer with a group spacing of $6.25 \mathrm{~m}$ and a total active length of $143.75 \mathrm{~m}$. Data acquisition was by an EG\&G Geometrics ES2420 instrument with a sampling rate of $1 \mathrm{~ms}$. A $360 \mathrm{~Hz}$ anti-aliasing filter was applied before the data was stored in demultiplexed SEG-D format. Navigation data were obtained by means of the ship's GPS-receiver. Processing was performed first at the University of Aarhus on a ND-570 computer using the software package Norseis (developed by GECO, Norway). Because of the very short streamer length compared to the depth of investigation (down to $\sim 3.6 \mathrm{~km}$ ) no velocity information could be derived from the data. A velocity model with spatially invariant velocities assigned to the different sequences was therefore applied for the normal move out correction. The stacking fold varied between 6 on the island slope and 3 in the basins.

The data were subsequently processed at GEOMAR in Kiel on a CONVEX computer and a SUN-workstation Sparc classic using the software package Geosys (developed by Prakla, Germany). After calculating numerous amplitude spectra, the data were resampled to 2 


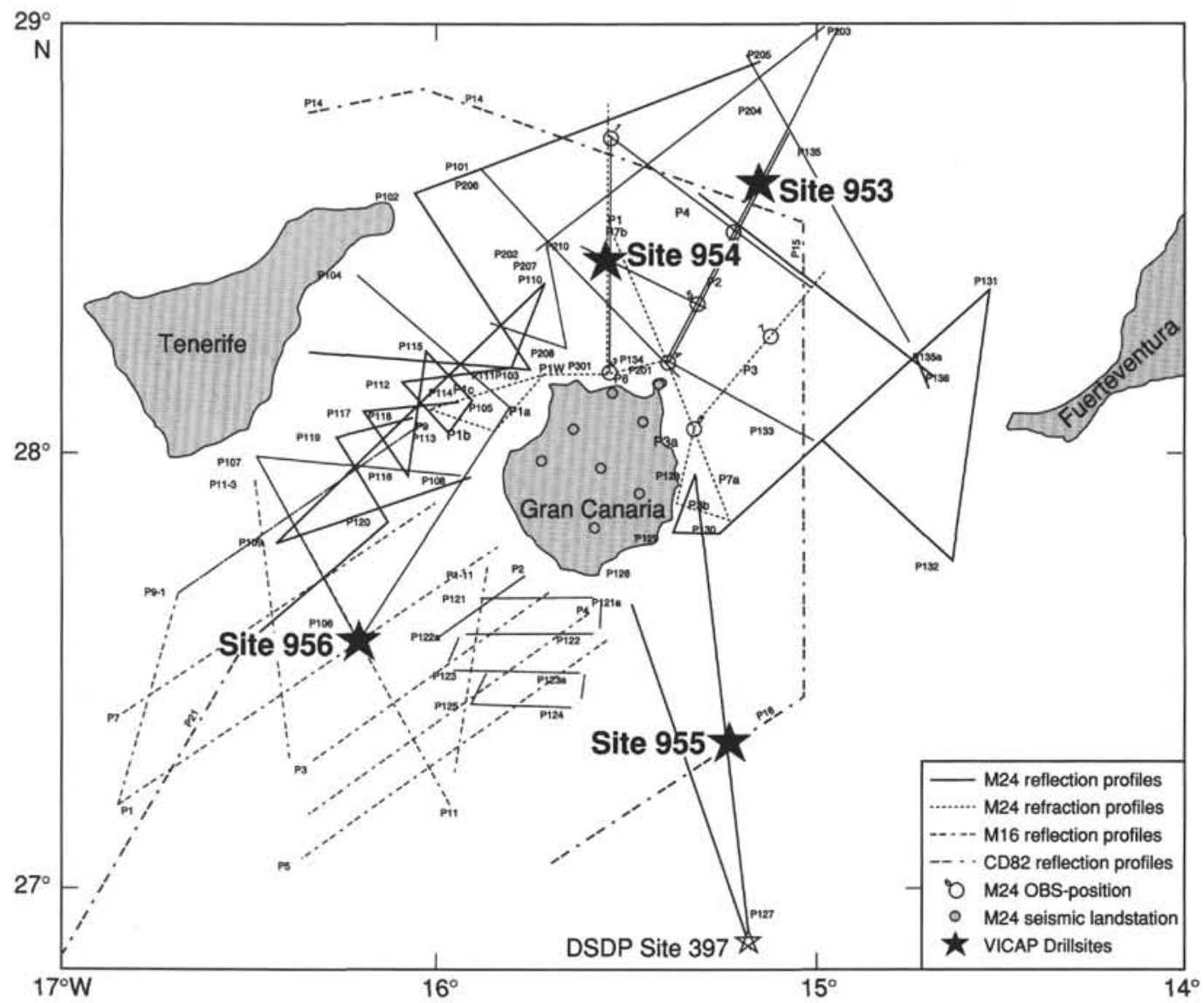

Figure 5. Location map with the tracks of the pre-cruise site surveys around Gran Canaria (Meteor Cruises 16 and 24, Charles Darwin Cruise 82).

ms with regard to economic processing, especially for the migration, which was the main goal for the processing in Kiel. Missing velocity information required a number of test migrations to be conducted with constant velocities using the very fast Stolt migration. Then a velocity model was developed as input for the final finite-difference migration in the fx-domain. An example of a migrated profile at Site 953 is shown in Figure 6 and in the back-pocket foldout; smaller parts of the seismic lines at Site 954 and 956 are shown in Figures 7 and 8.

The vertical resolution in the shallow part of the sections is around $5 \mathrm{~m}$. The sediments overlying the submarine island flanks (acoustic basement) of Gran Canaria, Tenerife, and Fuerteventura are penetrated. The depth to the top of the flank is up to $900 \mathrm{mbsf}$. Outside the flanks the penetration was up to $2.4 \mathrm{~s}$ two-way traveltime below seafloor. The extension of the submarine flanks of the volcanic islands could be mapped, and it was found that the edge of the flank of Gran Canaria extends 30 to $60 \mathrm{~km}$ away from the shoreline. The flank of Tenerife onlaps the steeper and older flank of Gran Canaria in the channel between the two islands.

The M24 profiles are connected to DSDP Site 397 (von Rad, Ryan, et al., 1979) and the seismic Reflectors R3 (Pliocene Roque Nublo Formation) and R7 (Miocene volcaniclastic debris flows) could be correlated from Site 397 to the southern apron of Gran Canaria. We are unable to correlate these reflectors to the basin north of $\mathrm{Gran} \mathrm{Ca}$ naria because slides in the channels between Gran Canaria and the neighboring islands Tenerife and Fuerteventura result in a seismic chaotic facies.

The earth's magnetic and gravity field were measured along with the seismic profiling. The high-resolution sediment echo sounding system PARASOUND had a penetration up to $100 \mathrm{mbsf}$ and the bathymetry was recorded by means of the HYDROSWEEP swath bathymetry. North of Gran Canaria a refraction seismic experiment was also carried out with a network of eight ocean-bottom seismographs and eight land stations on Gran Canaria. Two 321 Bolt air guns were used as seismic sources and the shot interval was generally 2 min (Schmincke and Rihm, 1994).

Meteor Cruise 16 (June 1991) completed the M24 data set with seismic lines of a total length of $\sim 950 \mathrm{~km}$ south of Gran Canaria and Tenerife (Wefer et al., 1992). The seismic equipment was supplied by the Institute of Geophysics (2.4-km-long 48-channel streamer) and the Institute of Biogeochemistry of the University of Hamburg (80m-long 6-channel streamer). HYDROSWEEP, PARASOUND, gravity, and magnetics were also recorded on M16.

Some of the proposed VICAP drill sites were surveyed in order to get additional crosslines during Charles Darwin Cruise 82 in November-December 1993 (University of Oxford).

\section{PRINCIPAL RESULTS}

\section{Introduction}

The evolution of oceanic island volcanoes represents a dynamic competition between growth by mantle melting processes and eruption and degradation by mass wasting processes. The VICAP drilling project was designed to better understand the way these large intraplate oceanic volcanic systems evolve and decay. We chose Gran Canaria as a prototype because of its 15 m.y. subaerial history and extreme spectrum of magma compositions and because its evolution has been studied in detail (Schmincke, 1982, 1994; Hoernle and Schmincke, 1993a, b). 


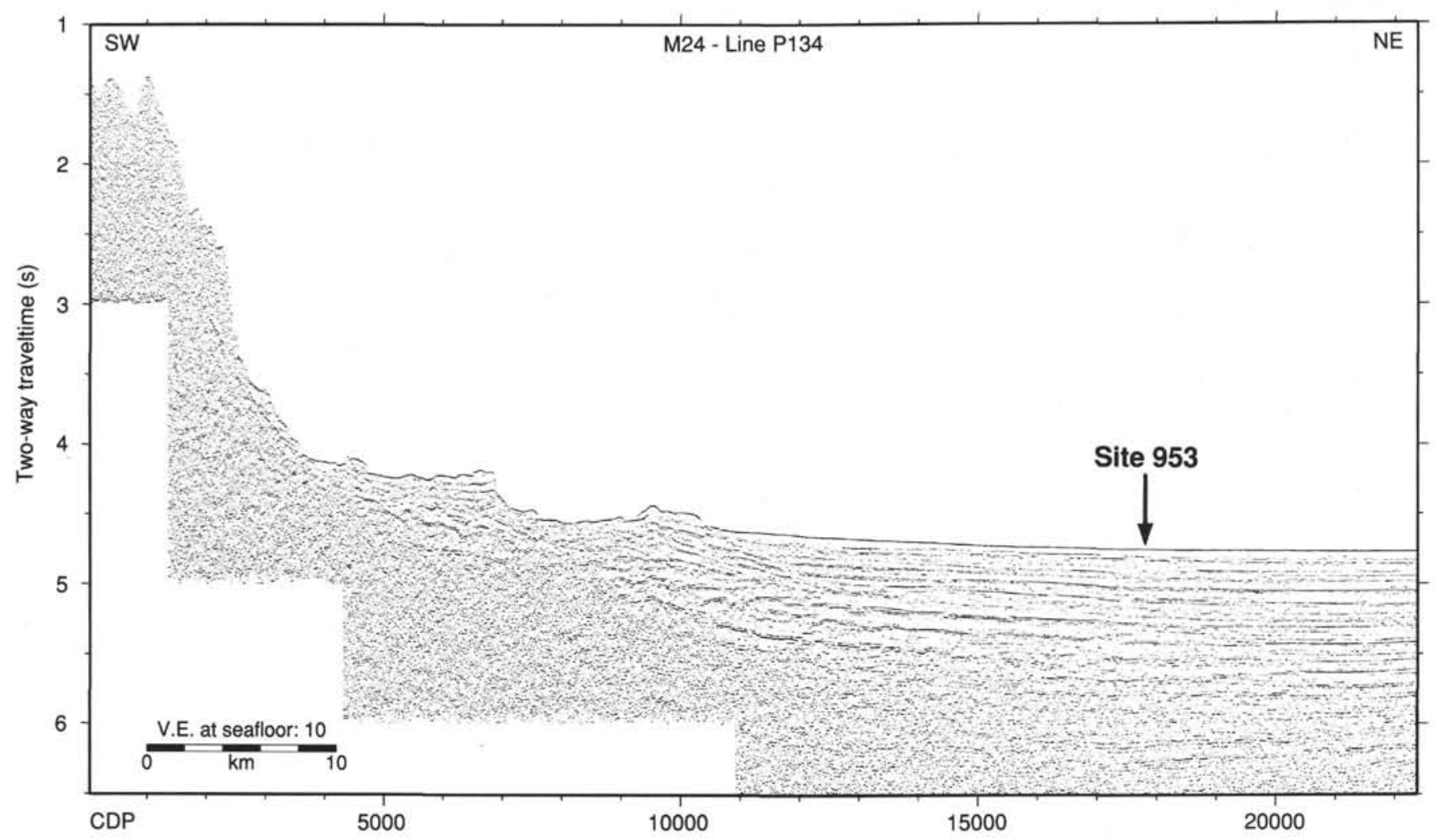

Figure 6. Reflection seismic profile (M24, Line 134) at Site 953. The line is time migrated (GEOMAR Kiel and University of Aarhus).

Four holes drilled north and south of the island (Fig. 9) penetrated a total of almost $3000 \mathrm{~m}$ and have demonstrated that the compositional evolution, growth, and mass wasting of an ocean island is reflected in the sediments of the adjacent volcaniclastic apron.

The marine record at Sites 953-956 shows an excellent first order correlation to the geological history of Gran Canaria. All major volcanic and nonvolcanic phases on this island are reflected in the ages, types and compositions of sediments (Fig. 10). The land-sea correlations were successful because of the geochemically distinct phases of volcanism on Gran Canaria and because the overall land-based stratigraphy has been documented in detail. Drilling at the VICAP sites during Leg 157 has demonstrated that the evolution of a volcanic island can be reconstructed by examining the lithostratigraphy of volcaniclastic sediments deposited in adjacent marine basins. The submarine sections obtained thus provide an additional dimension to refine and evaluate the timing, composition and emplacement mechanisms of volcanic material supplied from the island.

Sites 953 and 954 are located on the northern volcanic apron of Gran Canaria, and Sites 955 and 956 to the southeast and southwest, at distances ranging from 40 to $70 \mathrm{~km}$ from the island.

\section{Volcanic Evolution of Gran Canaria}

\section{Correlation of Subaerial Volcanic Phases with the Marine Volcaniclastic Record of the Volcanic Apron}

Drilling the submarine volcaniclastic apron has the advantage that material lost from subaerial sections through erosion is preserved in the marine environment. A number of sites must be drilled in several locations, however, to gain a balanced assessment of the island's volcanic evolution.

We anticipated that the general lithostratigraphy of all four drill sites would correlate closely with the volcanic stratigraphy of Gran
Canaria. Differences between the sites were also anticipated because of major geological differences in the geology of Gran Canaria (e.g., the general absence of post-Miocene volcanism in the southern half of the island), prevailing wind directions (which might disperse ashes from Tenerife more favorably to the south), proximity to Gran Canaria (Site 954 being located close to the island flank and thus representing the more proximal facies), and contrasting history of the sedimentary basins north and south of Gran Canaria.

Correlations of the marine volcaniclastic sediments in the drill sites with land-based counterparts were made using both macroscopic and microscopic visual analyses of sediment textures and mineral compositions, as well as XRF bulk-rock chemical analyses to determine the major and trace element compositions. These correlations were aided by the biomagneto-stratigraphic data. The biomagnetostratigraphic data in turn were aided by the lithologic land-sea correlations, especially where bio- and/or magnetic data were inconclusive.

Major and trace element abundances clearly allow us to distinguish between mafic and evolved rocks and between the Miocene and Pliocene rock suites. Even more subtle differences between Mogan peralkaline trachytes and low silica rhyolites and early and late Fataga trachyphonolites were recognized. Major changes in sediment (phenocryst) mineralogy throughout the whole sequence at all sites reflect known and dated changes on land. Without knowing the age of the sediments as determined by biomagnetostratigraphy, a rough age assignment with an uncertainty in some cases of $<0.2 \mathrm{~m}$.y., could have been made for certain layers based solely on the qualitative mineralogy of the sediments, aided by the chemical whole-rock composition.

The changes from submarine through emergent to subaerial shield and subsequent ash flow eruptions are especially well reflected in the downhole logs. The quad combination toolstring, geochemical, and Formation MicroScanner were successfully deployed openhole in 


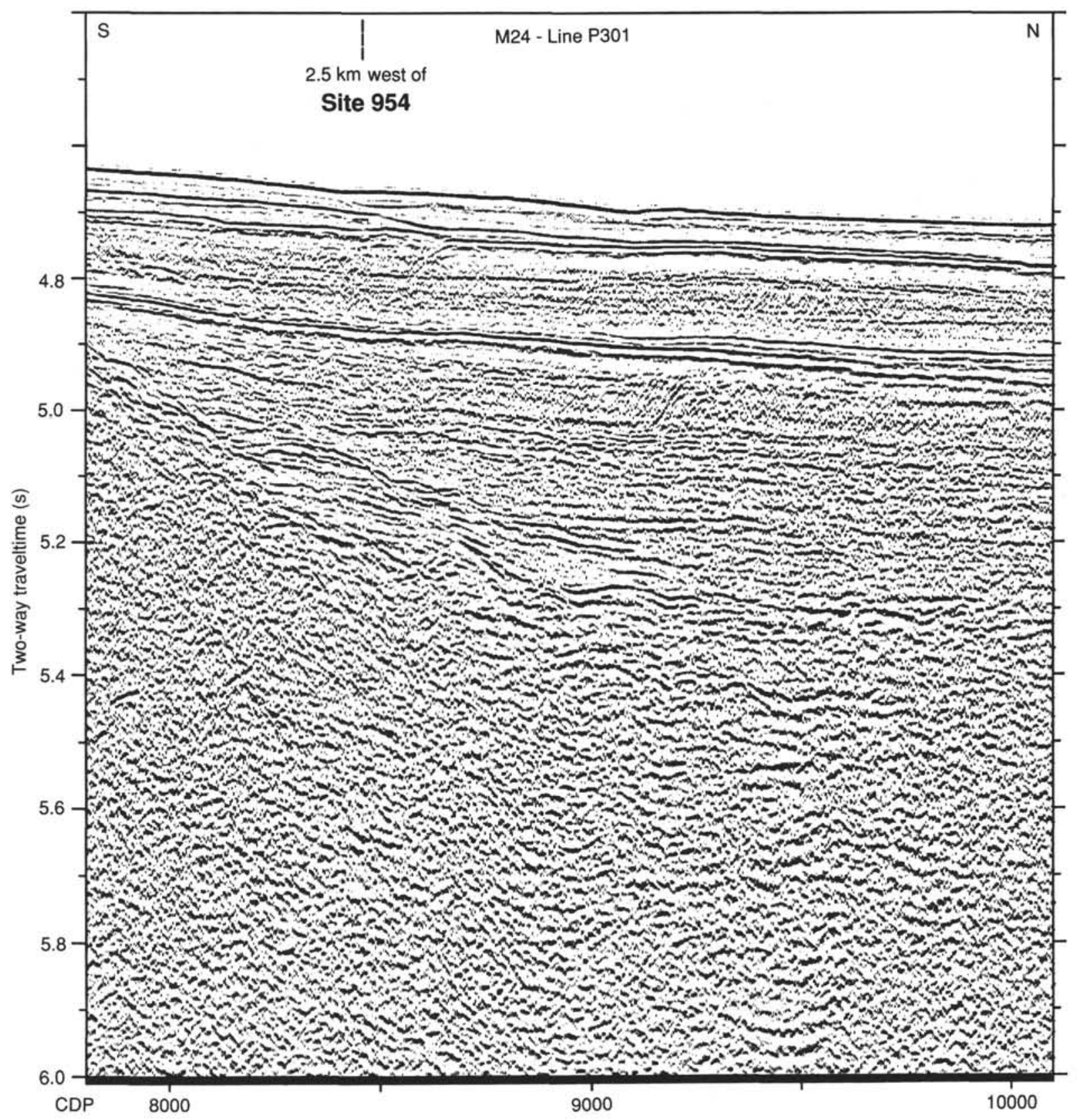

Figure 7. Part of reflection seismic profile (M24, Line 301) at Site 954. The line is time migrated (GEOMAR Kiel and University of Aarhus).

Sites 953, 955, and 956. The components of $\mathrm{K}, \mathrm{U}$, and Th derived from the total natural gamma-ray log are particularly diagnostic. The transition from the shield to the volcaniclastic sediments correlative to the Mogan Formation is characterized at all three sites by sharp increases in density, sonic velocity, and resistivity, as well as abrupt increases in K, Th, and U. Similarly, the abrupt decrease of K, U, and $\mathrm{Th}$, and, to a lesser degree, resistivity, reflects the pronounced decrease in supply of volcaniclastics in the volcanic hiatus above the Fataga Formation. Even the geochemically similar Mogan and Fataga Formations can be distinguished from each other by the patterns of the natural gamma ray log.

\section{Shield Phase}

The highest rate of volcaniclastic deposition corresponds to the mid-Miocene basaltic shield stage of Gran Canaria. Initial phases in- cluded deposition of thick, graded hyaloclastite tuffs and debris flows, some containing large clasts of subaerial basalts (the thickest single depositional unit exceeding $80 \mathrm{~m}$ ), which are possibly associated with large slump events. These are overlain by breccias and lapillistone that record the transition from shallow submarine to subaerial. Establishment of the subaerial shield prior to becoming covered by the rhyolitic ash flows is reflected in hundreds of thin finegrained turbidites totalling $40 \mathrm{~m}$ in thickness at Site 953 .

\section{Miocene Rhyolitic to Trachyphonolitic Explosive Volcanism}

On land, the shield basalts are overlain by $>200 \mathrm{~m}$ of peralkaline rhyolitic ignimbrites and minor lavas (Mogan Formation, 14.1-13.4 Ma) overlain by $>500 \mathrm{~m}$ of trachyphonolitic ignimbrites and lava flows (Fataga Formation, 13.4-9.5 Ma). Different facies of volcaniclastic sediments, correlated to both volcanic phases, occur at Sites 


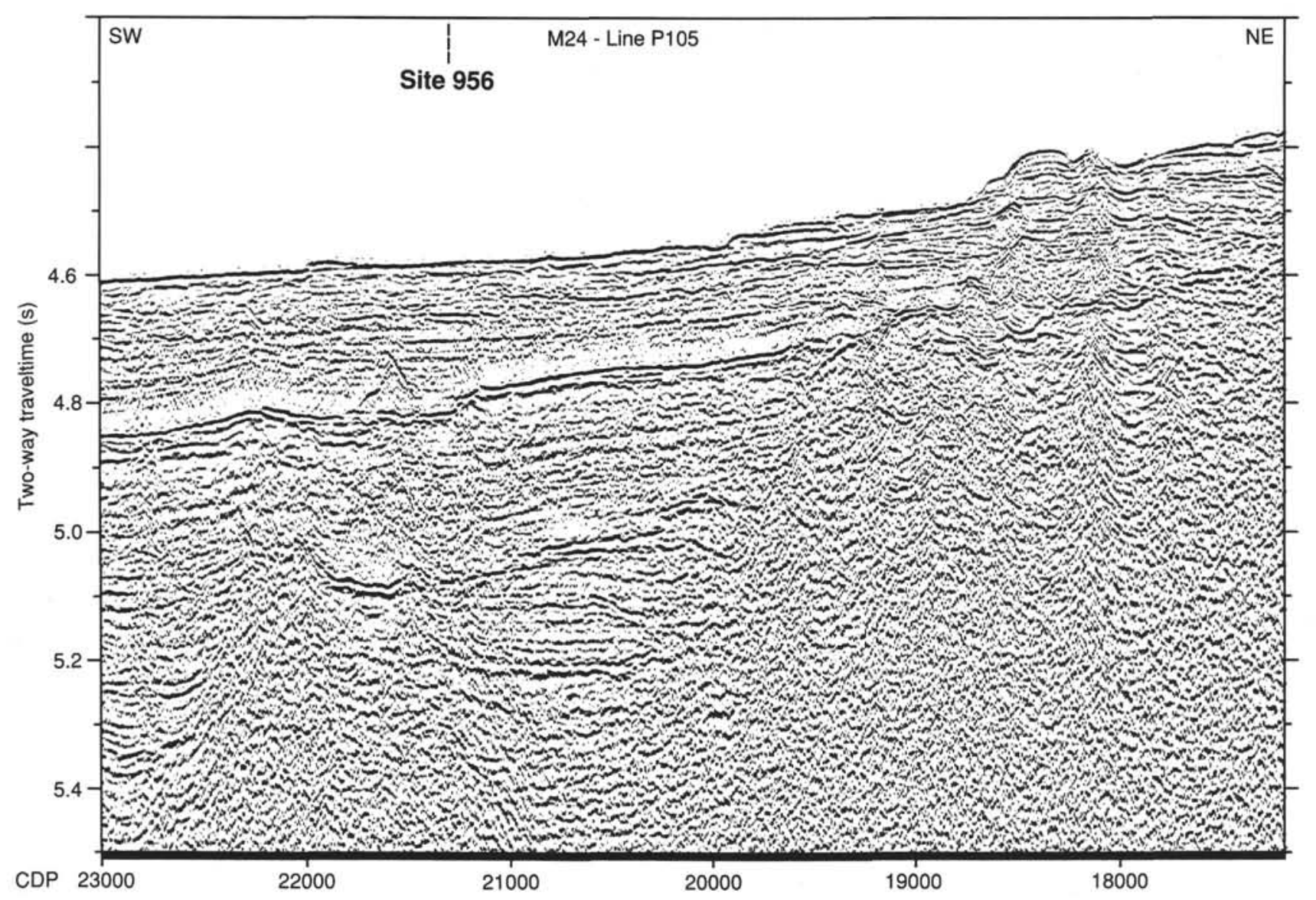

Figure 8. Part of reflection seismic profile (M24, Line 105) at Site 956. The line is time-migrated (Geomar Kiel and University of Aarhus).

953,955 , and 956 and range in thickness from 54-50 $\mathrm{m}$ (Mogan) and from 120 to $>250 \mathrm{~m}$ (Fataga). At three sites, up to $170 \mathrm{~km}$ apart, we recognized, based on mineralogy, the marine facies of cooling Unit P1, a 14.1 Ma ignimbrite that forms an important stratigraphic marker on Gran Canaria, separating the basaltic shield from the felsic volcanics. Two other volcaniclastic deposits at Site 955 were also correlated to ignimbrites $\mathrm{A}$ and $\mathrm{X}$, based on mineralogy. The chemical composition of abundant fresh glass, some possibly generated by quenching of dense hot ash flows upon entry into the sea, will be used to help geochemically correlate most of the 15 Mogan cooling units to volcaniclastic turbidites. This will contribute to a better understanding of the processes that occur during the passage of hot ash flows into water. Abundant alkali feldspars will be used in shorebased studies for a detailed single crystal dating that will aid high resolution correlation with biostratigraphic and paleomagnetic data, which are particularly continuous at Site 953.

The change from Mogan to Fataga felsic rocks (ignimbrites and lava flows of trachyphonolitic composition, erupted between $\sim 13.4$ and $9.5 \mathrm{Ma}$ ), characterized on land by the appearance of biotite, is also reflected in the sediments. The thickness of deposits consisting of volcaniclastic sediments intermixed with nonvolcanic pelagic sediments and other turbidites believed to be equivalent to the Fataga ranges from $250 \mathrm{~m}(\sim 500-750 \mathrm{mbs})$ at Site 953 , to $130 \mathrm{~m}(380-510$ $\mathrm{mbsf})$ at Site 955 , to $140 \mathrm{~m}$ (380-520 mbsf) at Site 956.

\section{Miocene Volcanic Hiatus}

An important volcanic hiatus on Gran Canaria between 4.5 to 9.5 Ma corresponds at all four drill sites to a period of very low volcani- clastic input to surrounding basins. Erosion of the island, apart from episodic flank collapses, does not appear to have contributed large volumes of coarse material to the apron during this hiatus. Significant influx of coarse volcaniclastic sediment to the deep sea apparently occurs only during and immediately after periods of active volcanism. The steady background erosion of the island-apart from episodic flank collapses-does not appear to contribute large volumes of coarse material to the apron. This observation could prove useful in evaluating the significance of different volcaniclastic facies in ancient rock successions and their relationship to the tempo of volcanic activity in the source region.

At all four sites, the accumulation rate based on integrated bioand magnetostratigraphy is at a minimum during the major nonvolcanic period between approximately 8 and $5 \mathrm{Ma}$. The absence of postMiocene volcanic activity in southern Gran Canaria is extremely well reflected in the marine sediments of the two southern Sites 955 and 956 by the near absence of volcanic material during this time interval.

\section{Pliocene Roque Nublo Stratocone and Pleistocene Volcanism}

The dominantly mafic Roque Nublo volcanics characterized by Ti-augite and hornblende on land were recognized in Sites 953 and 954 but not, as expected, in the southern sites. The post-Roque Nublo mafic lavas are especially well represented in the Pleistocene coarse sand sediments recovered in the northern sites.

Unusually high alkalinity in the absence of significant organic matter diagenesis, combined with high magnesium and lithium contents were observed at Site 954 . These $\mathrm{CO}_{2}$-charged effervescent pore waters are presumably due to the proximity of this drill site to 
Figure 9. Map of the central Canary Islands with locations of the proposed first- and second-priority VICAP drill sites.

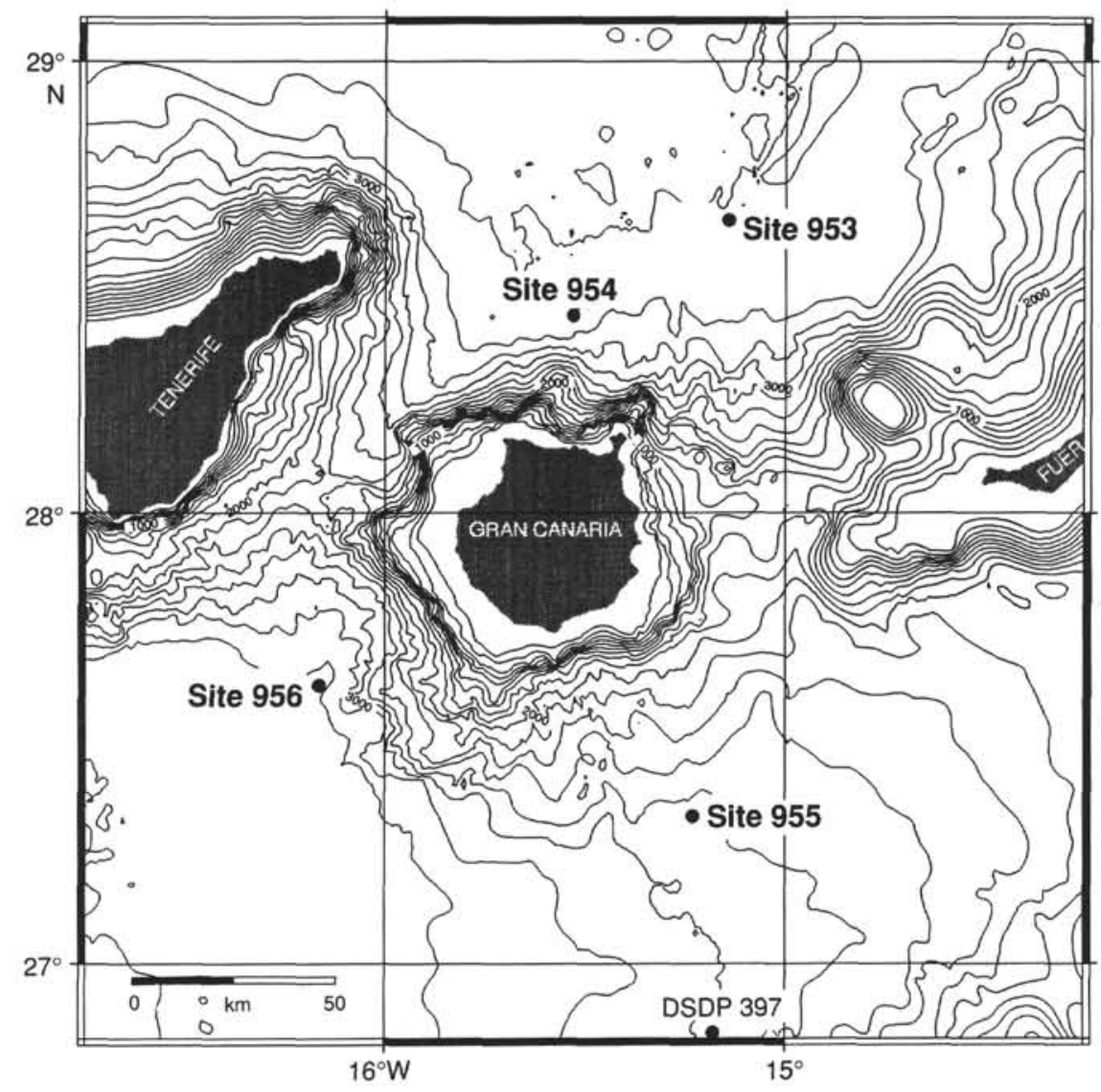

an area of Holocene volcanism in northern Gran Canaria, which is also reflected in the highest geothermal gradient $\left(52.7^{\circ} \mathrm{C} / \mathrm{km}\right)$ measured in any of the sites.

\section{Marine Volcaniclastic Sediments without Equivalent Deposits on Land}

In addition to land-sea correlations of volcanic sediments, we also sought to identify volcaniclastic deposits not preserved and/or recognized on land either because they are covered by younger formations, have been eroded, were formed below sea level, or are transported during eruptions chiefly to the sea.

\section{Shallow-water Shield Stage}

At Sites 953 and 956 very thick sequences of hyaloclastite tuffs and lapillistone form nearly uninterrupted sequences, at least $200 \mathrm{~m}$ and $140 \mathrm{~m}$ thick, respectively. The lack of interbedded nonvolcanic sediments at Site 953 and from 620-704 mbsf at Site 956 indicate very high sedimentation rates for this phase of submarine deposition and reflects high rates of volcanic production during the shield stage of oceanic volcanoes. These graded green hyaloclastite tuffs, lapillistones, and breccias (the major ones $>65 \mathrm{~m}$ thick) are interpreted as dominantly debris flow deposits. They consist of moderately to highly vesiculated shards and contain $30-70 \mathrm{vol} \%$ basaltic fragments, including oxidized scoria. Most basalt clasts at Site 953 have quench textures, which probably represent true submarine basalts, while at Site 956 subaerially erupted basalts dominate among the lithic clasts. Lithologic Unit VII at Site 953 may be older than Gran Canaria because it is separated from Unit VI both seismically and by the only thick nonvolcanic sediment bed in the lower $300 \mathrm{~m}$ of the hole, and because they differ lithologically.
Part of the island must have emerged during generation of these debris flows, whose generation may have been associated with collapse of the unstable upper part of the volcano encompassing the shallow submarine and subaerial part. Deposits representing the deep-water stage consisting entirely of nonvesicular hyaloclastites as encountered at Site 397 (Schmincke and von Rad, 1979) were not recovered at any of the sites.

The main reflector interpreted in Sites 953, 954, and 956 to represent volcanic basement (i.e., the flank of the shield volcano prior to burial by later sediments) coincides with volcaniclastic breccias. At Site 953 (Unit VI, 889-969 mbsf) these consist largely of basaltic sandstone, lapillistone, and breccia. Their contents range widely from hyaloclastites with basalt fragments to highly altered, nearly monomict hyaloclastites containing altered sideromelane shards and basaltic rock fragments, to silt- and sandstones mixed with varying amounts of biogenic debris, and volcanic clasts from several formations. The rocks are interpreted to reflect the change from very shallow submarine emergent to subaerial volcanism. At Site 954 (Unit IV, 406-446 mbsf) about $40 \mathrm{~m}$ of basaltic breccia, consisting of a mixture of subaerially derived and very shallow submarine clasts (hyaloclastite, vesicular pillow rims), are similarly thought to have been formed when lavas from the early island stage entered the sea, were broken, and the basaltic fragments were mixed with shallow water bioclasts to form a characteristic facies.

\section{Subaerial Shield Stage}

Sediments believed to represent the subaerial stage of the shield prior to being covered by Mogan ash flows were only found at Site 953 (Unit V, 850-889 mbsf). The most significant sediment type in this interval consists of hundreds of small turbidite units of volcanic sand and silt, many only a few centimeters thick. These turbidites ap- 


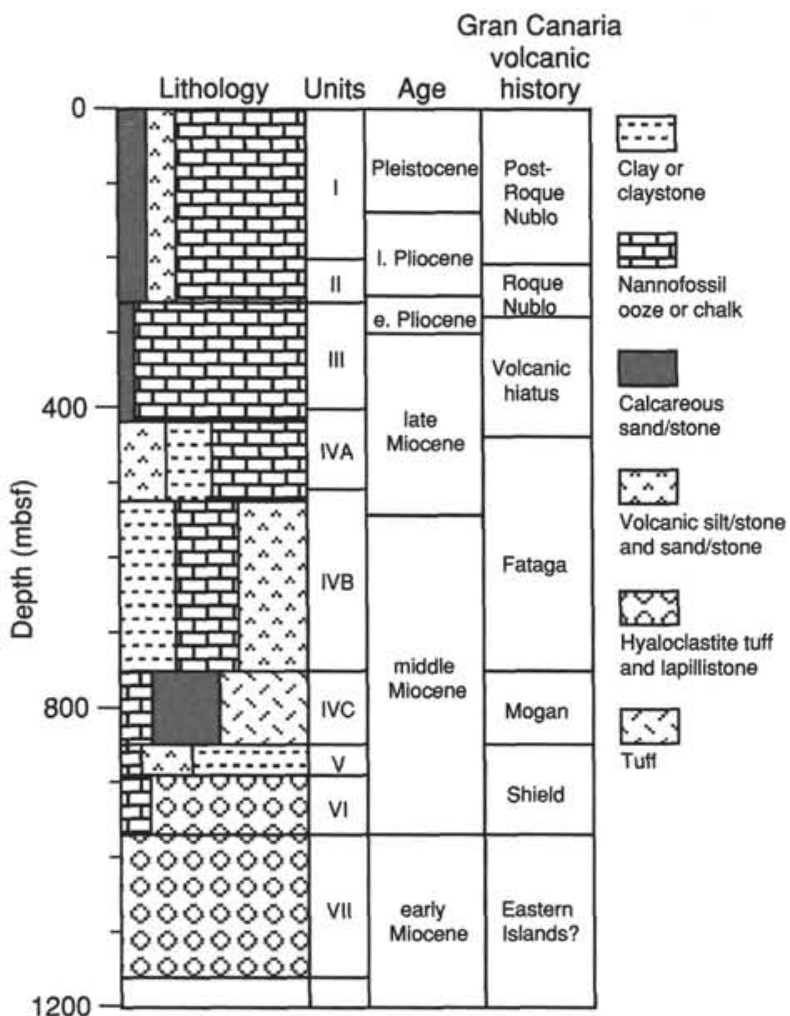

Figure 10. Lithostratigraphy of Site 953 and correlation to subaerial lithostratigraphy of Gran Canaria.

parently record the growth and erosion of the subaerial shield after the lavas entered the sea. Land evidence indicates that lava flows are generally much smaller than those on Kilauea Volcano or other Hawaiian volcanoes, and during much of the subaerial activity lava flows may have been too short to reach the sea in Gran Canaria.

\section{Miocene Vitric Tuffs}

Thick, middle Miocene, fine-grained vitric tuffs consisting entirely of glass shards were recovered from Sites 953 and 956 . This unit is correlated to the Mogan phase on Gran Canaria which was dominated by major ash flow eruptions. These highly vitric silts and sands of similar age to the late Fataga and early Mogan volcanic phases are not easy to interpret. They either represent (1) fallout tephra not recognized on land-which is unlikely because of excellent outcrops and detailed field work, (2) deposits not preserved on land, (3) co-ignimbrite ashes elutriated during emplacement of the ignimbrites on land or during entry into the sea and deposited in the sea, or (4) abrasion of large pumice floats that are commonly observed after large eruptions.

\section{Sideromelane-rich Volcanic Sand Layers}

Sideromelane-rich volcanic sand layers in the Pleistocene sediments at Site 953 may represent either submarine eruptions or flow of lava into the sea possibly connected with the young volcanic complex on the Las Palmas Peninsula or distal turbidites related to larger slumps.

\section{High Resolution Correlation of Biostratigraphic and Paleomagnetic Time Scales Fine-tuned by Single-crystal Physical Dating of All Layers}

The excellent continuous magnetobiostratigraphic record from the middle Miocene to the Holocene from Site 953 presents a unique opportunity to calibrate these time scales against compositionally correlated ash layers to the dated land deposits and dating of numerous feldspar and biotite-bearing Miocene ash layers drilled. We anticipate that current competing models for the mid-Miocene time scales will be resolved as a result of time-scale correlation and dating.

\section{Contribution from Neighboring Islands}

Prior to drilling, we were uncertain whether the volume and composition of volcanic detritus contributed from neighboring islands would make it difficult to reconstruct the volcanic evolution of Gran Canaria.

Pico de Teide on the neighboring island of Tenerife towers 3714 masl and is the third tallest volcano after Mauna Kea and Mauna Loa, but it is composed dominantly of phonolitic rocks. It appears to have grown above a $\sim 2000 \mathrm{~m}$ high basaltic basement entirely during the past 2 m.y. (Ancochea et al., 1990). Pleistocene ash and pumice layers recovered at all four drill sites are most numerous and thickest at Site 956, the site closest to the Cañadas caldera at the base of Pico de Teide on Tenerife, the presumed source area. Compositional analysis of the tephra layers will allow us to monitor the temporal and compositional evolution of the eruptive phases in detail, assess the magnitude of major explosive eruptions and determine the length of repose periods as an aid in predicting future eruptions. The greater thickness of fallout tephra layers at this southwestern site also confirms that paleowind directions resembled the present ones.

Volcanic material from other adjacent islands was not unequivocally recognized with the possible exception of the very basal hyaloclastites (Unit VII) at Site 953, which may have come from Fuerteventura.

\section{Basin Evolution North and South of Gran Canaria}

One objective of Leg 157 aimed to record and contrast volcaniclastic and pelagic sedimentation in two different basins, both of which developed along with the emergence of large volcanic islands from east to west, but which differed appreciably in their source areas. Prior to the growth of Gran Canaria only the east Canary Ridge divided the incipient basins. Two drill sites had thus been placed in the northern basin and two in the southern basin. The northern sites (953 and 954) are sheltered from Africa behind the barrier of the older eastern Canary Islands.

The differences in nonvolcanic sediments and thus basin history between the two basins, which are more pronounced than had been anticipated, are reflected both in the type of sediments as well as the depositional and postdepositional processes. There are similarities in the type of sediment evolution that are independent from the influence of the volcanic island source areas.

\section{Green Organic-rich Sediments}

Green organic-rich sediments are almost absent from the northern sites. The only influx of sediments from Africa to Site 953 may be the green, slightly organic-rich turbidites in Subunits IVb and c, which also contain some quartz at their bases. The ridge between Gran Canaria and Fuerteventura may have been much lower at that time, allowing minor sediment mass flows to enter the sedimentary basin north of Gran Canaria. No green turbidites were found at Site 954. At Site 955 green oozes are common throughout cores and the methane concentration ranges from $2000-40,000 \mathrm{ppm}$, compared with 2-12 $\mathrm{ppm}$ at the other three sites. Green, organic-rich sediments are less common in Site 956 than 955 but are significantly more abundant than in the northern sites. Island upwelling along the southeastern coast of Tenerife may have been more important to generate organicrich sediments at Site 956 than influx from the African continental margin.

\section{Quartz-rich Sediments}

The amount of quartz in the silt-sand fraction at Sites 953 and 954 is insignificant, in contrast to Sites 955 and 956 and DSDP Site 397 
(Arthur et al., 1979). Quartz-rich sands occur in thin millimeter- to centimeter- (rarely up to $2 \mathrm{~m}$ ) thick layers throughout several cores from Site 955. Quartz is present in many coarser sediments at Site 956 but is less pronounced than in that found at Site 955 . The nearabsence of quartz at Sites 953 and 954 and its abundance at Site 955 suggests that the dominant mode of transport of quartz found at Sites 397,955 , and 956 was by bottom currents or sediment slides rather than by wind.

\section{Slump Deposits}

Slumping of unconsolidated sediments is a common feature of the slope environment adjacent to active oceanic islands and is a complicating factor in the reconstruction of the volcanic history from the sediments. Some distinct episodes can be correlated between the sites drilled during Leg 157 implying that phases of slumping may be widespread and are possibly related to volcano-tectonic activity.

Slump deposits are almost absent at Site 953, but they are common at all other sites in ooze sediments in the upper part of the holes and were interpreted as hiatuses. At Site 954 we found at least three probable hiatuses in the lower Pliocene at about 1-1.6 Ma, in the lower Pliocene from roughly 4.4 to $5.3 \mathrm{Ma}$, and in the lower upper Miocene from roughly 8.8-9.4 Ma. Two similar age hiatuses were also present at Site 955. Here, removal of the late Pliocene section and repetition of early Pliocene within the late Pliocene were found within the slumped, chaotic facies of Unit Ia. Two hiatuses were also found at Site 956. The first is present between 399 and $413 \mathrm{mbsf}$ and spans a minimum of $0.6 \mathrm{Ma}$ between 8.8 and $9.4 \mathrm{Ma}$, suggesting a regional event. The second is between 436 and 446 and spans a minimum of $0.8 \mathrm{Ma}$ between 10 and $10.8 \mathrm{Ma}$.

At DSDP Site 397 major slump deposits (greater than $\sim 300 \mathrm{~m}$ thick) were found in the lower Miocene. Arthur et al. (1979) concluded that "No displaced sediment was deposited (late Miocene to Holocene) at Site 397 during the hemipelagic drape phase." At Site 955 all sediment of the upper $200 \mathrm{~m}$ is displaced with common reversals, hiatuses, etc. The strong similarities to Site 397 , with shallow water faunas and coarse quartz grains, suggest similar transport for much of that sediment.

The hiatus between $\sim 8.8$ and $9.4 \mathrm{Ma}$ that was recognized at Sites 954,955 , and 956 coincides with the end of a phase of massive outpouring (possibly several $100 \mathrm{~m}$ in total thickness) of trachyphonolite lava flows at the end of the Fataga phase on Gran Canaria, but the exact mechanism by which this major event could have influenced the subsequent hiatus is unknown. The sediments at Site 955, and to a lesser extent at Site 956, are more clay-rich than those in the northern sites as reflected in the lower carbonate contents of both pelagic and turbiditic sediments. This suggests a significant contribution of clays from the African continental margin.

\section{Basin Evolution from the Middle Miocene to Holocene}

During the middle Miocene, very minor quartz and organic-rich turbidites from the African margin were able to reach the basin north of Gran Canaria (Site 953). As there is presently a bathymetric barrier to the influx of such material this implies that there was a deeper pathway in the past or, less likely, a different source of turbidites that were able to pass into the northern basin.

\section{Pore-water Chemistry, Alteration, and Diagenesis of Organic Matter}

One of the objectives and expectations of the leg was to document the influence of volcanic glass-rich sediments, especially the highly contrasting, extremely evolved and very glass-rich volcaniclastic formations (chiefly Mogan and Fataga), on the composition of the pore waters. The proximity to the island and hence presumably higher heat flow was thought to have led to higher degrees of alteration. Despite the geographic proximity of the VICAP sites to Gran Canaria, porewater profiles indicate that very different diagenetic processes dominate the middle Miocene-Holocene sequences: Site 953 is dominated by fluid-rock interaction between pore waters, volcanic glasses, and minerals; Site 954 displays large geochemical anomalies associated with levels of carbonated pore waters, and it is speculated that these unusual fluid compositions relate to Holocene volcanic activity in northern Gran Canaria; at Site 955, organic matter located principally in slumped sediments derived from the northwestern African margin, is driving intense sulfate reduction and methanogenesis at shallow depths, while the deeper part of the sediment column contains saline brines, possibly originating from the leaching of African shelf evaporites.

\section{Seismic Stratigraphy}

Volcaniclastic sequences are known to contain good reflectors, but the nature of single reflectors or groups of reflectors is commonly difficult to predict. In fact the plan for drilling the clastic apron of Gran Canaria arose from the drilling of major reflectors during Leg $47 \mathrm{~A}$, originally thought to represent the Cretaceous/Tertiary boundary, but which turned out to be middle Miocene volcaniclastic debris flows (Schmincke and von Rad, 1979). One of the major objectives of the cruise was therefore to intersect at least some major reflectors and compare the predicted depth and stratigraphic correlation and rock type.

Most of the seismic profiles outside the island flanks in the VICAP area are characterized by an abundance of reflectors with good continuity. The major part of the reflectors seem to originate as interference patterns generated by reflections from sequences of closely spaced interfaces between beds of fine-grained hemipelagic sediments with subtle differences in acoustic impedance. Some of the most conspicuous reflectors observed in the northern basin are volcaniclastic sediments that have densities and seismic velocities that exceed the densities and velocities in the hemipelagic sediments. In contrast, most reflectors in the southern basin appear to correlate with major hiatuses as recognized in the accumulation curves. The basement reflector at Site 955 turned out to be the top of volcaniclastic sediments equivalent to the Mogan Formation while at Sites 956, 953 , and 954 the acoustic basement correlated with the top of the basaltic debris flow deposits of the shield stage.

\section{SUMMARY}

In summary, the evolution of the volcanic apron of Gran Canaria and its detailed correlation with the land record can serve as a model that will improve assessment of the significance of volcaniclastic facies in ancient rock successions, their relationship to the tempo of volcanic activity and the past volcanic, petrologic, and plate tectonic environments of sedimentary basins adjacent to volcanic source regions. Drilling, in combination with the high resolution seismic data and the land record will allow more realistic calculations of magma production rates and thus mantle dynamics in hot spot regions. The great thickness of hyaloclastites and debris flows at the base of the two deepest holes supports the conclusion, based on dating the shield basalts, that the eruptive rate during the initial and major growth phase of the island was very high.

\section{REFERENCES}

Ancochea, E., Fúster, J.M., Ibarrola, E., Cendrero, A., Coello, J., Hernán, F., Cantagrel, J.M., and Jamond, C., 1990. Volcanic evolution of the island of Tenerife (Canary Islands) in the light of new K-Ar data. J. Volcanol. Geotherm. Res., 44:231-249

Ancochea, E., Hernán, F., Cendrero, A., Cantagrel, J.M., Fúster, J.M., Ibarrola, E., and Coello, J., 1993. Constructive and destructive episodes in 
the building of a young oceanic island, La Palma, Canary Islands, and genesis of the Caldera de Taburiente. J. Volcanol. Geotherm. Res. 60:243-262.

Arthur, M.A., von Rad, U., Cornford, C., McCoy, F.W., and Sarnthein, M., 1979. Evolution and sedimentary history of the Cape Bojador continental margin, northwestern Africa. In von Rad, U., Ryan W.B.F., et al., Init. Repts. DSDP, 47 (Pt. 1): Washington (U.S. Govt. Printing Office), 773 816.

Bogaard, P., Schmincke, H.-U., Freundt, A., Hall, C., and York, D., 1988. Eruption ages and magma supply rates during the Miocene evolution of Gran Canaria: single crystal ${ }^{40} \mathrm{Ar} /{ }^{39} \mathrm{Ar}$ laser ages. Naturwissenschaften, 75:616-617.

Bosshard, E., and Macfarlane, D.J., 1970. Crustal structure of the western Canary Islands from seismic refraction and gravity data. J. Geophys. Res., 75:4901-4918.

Dana, J.D., 1849. The United States Exploring Expedition during the Years 1838 1839, 1840, 1841, 1842 (Vol. 10): Geology: Philadelphia (Sherman).

Dash, B.P., and Bosshard, E., 1968. Crustal studies around the Canary Islands. Proc. Int. Geol. Congr. 23rd Sess., 1:249-260.

Funck, T., Dickmann, T., Rihm, R., Krastel, S., Lykke-Andersen, H., and Schmincke, H.-U., in press. Reflection seismic investigations in the volcaniclastic apron of Gran Canaria and implications for its volcanic evolution. Geophys. J. Int.

Hoernle, K., and Schmincke, H.-U., 1993a. The petrology of the tholeiites through melilite nephelinites on Gran Canaria, Canary Islands: crystal fractionation, accumulation, and depth of melting. J. Petrol., 34:573578.

Hoernle, K., and Schmincke, H.-U., 1993b. The role of partial melting in the 15-Ma geochemical evolution of Gran Canaria: a blob model for the Canary Hotspot. J. Petrol., 34:599-627.

Holik, J.S., Rabinowitz, P.D., and Austin, J.A., 1991. Effects of Canary Hot Spot volcanism on structure of oceanic crust off Morocco. J. Geophys. Res., 96:12039-12067.

Le Bas, M.J., Rex, D.C., and Stillman, C.J., 1986. The early magmatic chronology of Fuerteventura, Canary Islands. Geol. Mag., 123:287-298.

Lipman, P.W., Normark, W.P., Moore, J.G., Wilson, J.B., and Gutmacher, C.E., 1988. The giant submarine Alika debris slide, Mauna Loa, Hawaii. J. Geophys. Res., 93:4279-4299.

Luyendyk, B.P., and Bunce, E.T., 1973. Geophysical study of the northwest African margin of Morocco. Deep-Sea Res., 20:537-549.

Lyell, C., 1830-1833. Principles of Geology (Vols. 1-3): London (John Murray).

McDougall, I., and Schmincke, H.-U., 1976. Geochronology of Gran Canaria, Canary Islands: age of shield-building volcanism and other magmatic phases. Bull. Volcanol., 40:1-21.

Menard, H.W., 1956. Archipelagic aprons. AAPG Bull., 40:2195-2210.

Moore, J.G., Clague, D.A., Holcomb, R.T., Lipman, P.W., Normark, W.R., and Torresan, M.E., 1989. Prodigious submarine landslides on the Hawaiian Ridge. J. Geophys. Res., 94:17465-17484.

Moore, J.G., and Fiske, R.S., 1969. Volcanic substructure inferred from dredge samples and ocean-bottom photographs, Hawaii. Geol. Soc. Am. Bull., 80:1191-1201.
Morgan, W.J., 1972. Plate motions and deep mantle convection. Mem.Geol. Soc. Am., 132:7-22.

Morgan, W.J., 1983. Hotspot tracks and the early rifting of the Atlantic. Tectonophysics, 94:123-139.

Schmincke, H.-U., 1976. The geology of the Canary Islands. In Kunkel, G. (Ed.), Biogeography and Ecology in the Canary Islands: The Hague (W. Junk), 67-184.

Schmincke, H.-U., 1982. Volcanic and chemical evolution of the Canary Islands. In von Rad, U., Hinz, K., Sarnthein, M., and Seibold, E. (Eds.), Geology of the Northwest African Continental Margin: Berlin (Springer), 273-306.

Schmincke, H.-U., 1994. Geological Field Guide of Gran Canaria (6th ed.): Kiel (Pluto Press).

Schmincke, H.-U., and Rihm, R., 1994. Ozeanvulkan 1993, Cruise No. 24. 15 April-9 May 1993. METEOR-Berichte, Univ. Hamburg, 94-2.

Schmincke, H.-U., and Staudigel, H., 1976. Pillow lavas on central and eastern Atlantic Islands (La Palma, Gran Canaria, Porto Santo, Santa Maria). Bull. Soc. Geol. Fr., 18:871-883.

Schmincke, H.-U., and von Rad, U., 1979. Neogene evolution of Canary Island volcanism inferred from ash layers and volcaniclastic sandstones of DSDP Site 397 (Leg 47A). In von Rad, U., Ryan, W.B.F., et al., Init. Repts. DSDP, 47 (Pt. 1): Washington (U.S. Govt. Printing Office), $703-$ 725.

Staudigel, H., and Schmincke, H.-U., 1984. The Pliocene seamount series of La Palma/Canary Islands. J. Geophys. Res., 89:11195-11215.

von Buch, L., 1825. Physikalische Beschreibung der Canarischen Inseln: Berlin (Gedruckt Druckerei K. Akad. Wissenschaften).

von Fritsch, K., 1867. Reisebilder von den Canarischen Inseln: Gotha (Petermanns Geogr. Mitt, Ergänzungsheft), 5(22):1-44.

von Rad, U., Ryan, W.B.F., et al., 1979. Init. Repts. DSDP, 47 (Pt. 1): Washington (U.S. Govt. Printing Office).

Watkins, J.S., and Hoppe, K.W., 1979. Seismic reflection reconnaissance of the Atlantic margin of Morocco. In Talwani, M., Hay, W., and Ryan, W.B.F. (Eds.), Deep Drilling Results in the Atlantic Ocean: Continental Margins and Palaeoenvironment. Am. Geophys. Union, Maurice Ewing Ser., 3:205-217.

Watts, A.B., and ten Brink, U.S., 1989. Crustal structure, flexure, and subsidence history of the Hawaiian Islands. J. Geophys. Res., 94:10473-10500.

Watts, A.B., ten Brink, U.S., Buhl, P., and Brocher, T.M., 1985. A multichannel seismic study of lithospheric flexure across the HawaiianEmperor seamount chain. Nature, 315:105-111.

Wefer, G., Schulz, H.D., Schott, F., and Hirschleber, H.B., 1992. Atlantik 91-Expedition, Reise Nr. 16, 27 März-8 Juli 1991. METEOR-Berichte, Univ. Hamburg, 92-2.

Wilson, J.T., 1963. A possible origin of the Hawaiian Islands. Can. J. Phys., 41:863-870.

Wissmann, G., 1979. Cape Bojador slope, an example for potential pitfalls in seismic interpretation without the information of outer margin drilling. In von Rad, U., Ryan, W.B.F., et al., Init. Repts. DSDP, 47 (Pt. 1): Washington (U.S. Govt. Printing Office), 491-499.

\section{Ms 157IR-102}

